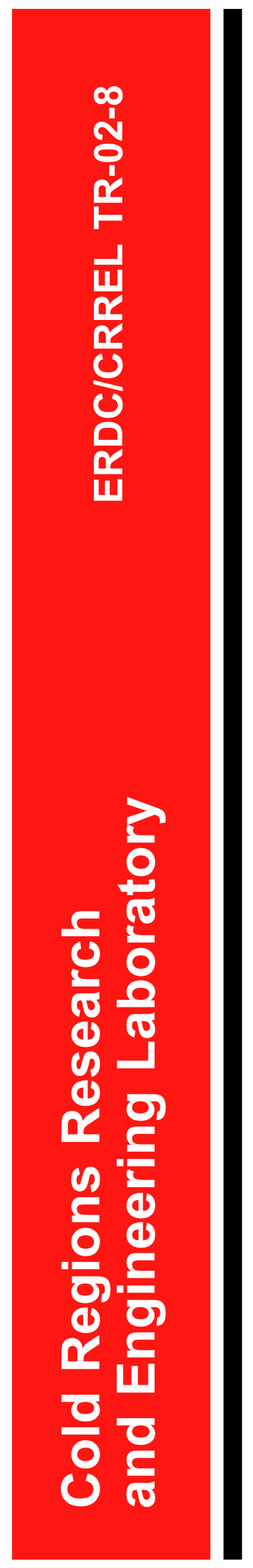

\title{
Videomonitoring Performance of the St. Marys River Ice Islands and Ice Boom
}

Andrew M. Tuthill and John J. Gagnon

May 2002 
Abstract: In 1997, six islands were constructed to stabilize the ice cover at the entrance to the Little Rapids Cut on the St. Marys River at Sault Ste. Marie, Michigan. It was hoped that the artificial islands would eliminate the need for an ice retention boom installed annually since 1974 by the Corps of Engineers. The U.S. Army Cold Regions Research and Engineering Laboratory
(CRREL) videomonitored the performance of the ice control islands during the winters of 2000 and 2001. Conclusions were that, although the islands helped stabilize the ice cover and protected the ice boom from impacts from large ice floes, the boom should still be installed as it significantly speeds ice cover formation at the Little Rapids Cut entrance.

How to get copies of ERDC technical publications:

Department of Defense personnel and contractors may order reports through the Defense Technical Information Center:

DTIC-BR SUITE 0944

8725 JOHN J KINGMAN RD

FT BELVOIR VA 22060-6218

Telephone (800) 225-3842

E-mail help@dtic.mil msorders@dtic.mil

WWW http://www.dtic.mil/

All others may order reports through the National Technical Information Service:

NTIS

5285 PORT ROYAL RD

SPRINGFIELD VA 22161

Telephone (703) 487-4650

(703) 487-4639 (TDD for the hearing-impaired)

E-mail_orders@ntis.fedworld.gov

WWW http://www.ntis.gov/index.html

For information on all aspects of the Engineer Research and Development Center, visit our World

Wide Web site:

http://www.erdc.usace.army.mil 


\section{Technical Report ERDC/CRREL TR-02-8}

\section{Videomonitoring Performance of the St. Marys River Ice Islands and Ice Boom}

Andrew M. Tuthill and John J. Gagnon

May 2002 


\section{PREFACE}

This report was prepared by Andrew M. Tuthill, Research Hydraulic Engineer, and John J. Gagnon, Civil Engineering Technician, Ice Engineering Research Group, RS/GIS Water Resources Branch, U.S. Army Engineer Research and Development Center (ERDC), Cold Regions Research and Engineering Laboratory (CRREL), Hanover, New Hampshire.

Funding for this research was provided by the Soo Area Office of the Detroit District of the U.S. Army Corps of Engineers. The Cold Regions Engineering Program Civil Works work units Ice Mitigation for Navigable Rivers and Winter Operation and Maintenance of Corps Structures also helped support this effort.

The authors thank the Soo Area Office and the U.S. Coast Guard at Sault Ste. Marie, Michigan, for their assistance throughout the study.

This publication reflects the personal views of the authors and does not suggest or reflect the policy, practices, programs, or doctrine of the U.S. Army or Government of the United States. The contents of this report are not to be used for advertising or promotional purposes. Citation of brand names does not constitute official endorsement or approval of the use of such commercial products. 


\section{CONTENTS}

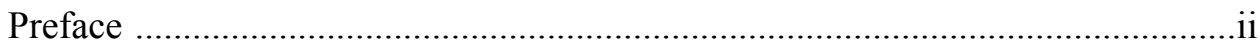

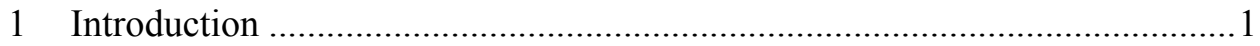

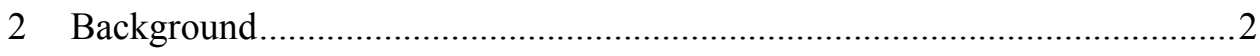

3 Ice regime on the St. Marys River and ice boom performance.......................6

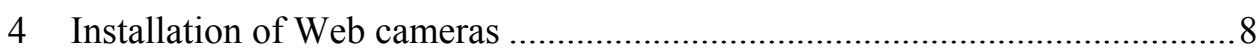

5 Factors affecting ice cover formation and recent trends ..............................11

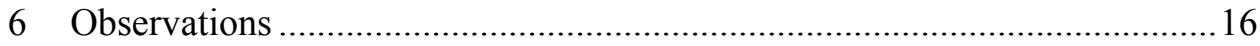

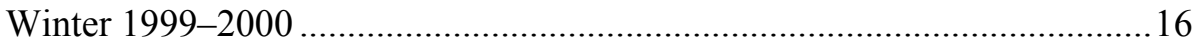

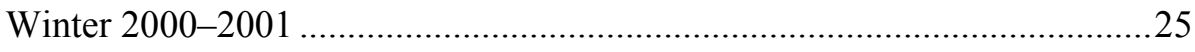

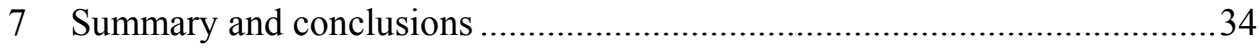

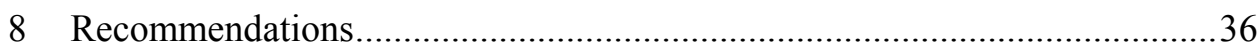

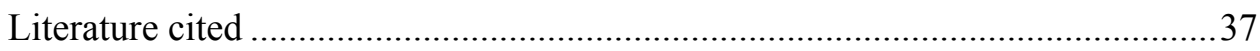

\section{ILLUSTRATIONS}

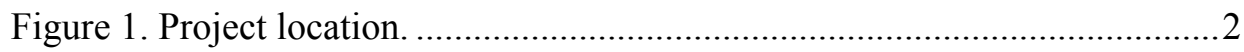

Figure 2. Project area. ................................................................................ 3

Figure 3. Recommended alternative from the 1996 study. ................................ 4

Figure 4. Completed ice stabilization islands and east arm of ice boom,

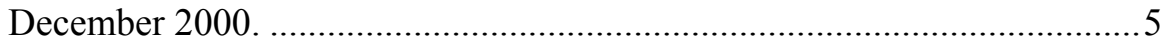

Figure 5. Water velocity on the St. Marys River upstream of Little Rapids Cut. 6

Figure 6. Sault Ste. Marie's 210-ft-high Tower of History................................ 8

Figure 7. Tower at Mission Point.................................................................... 9

Figure 8. Pan-tilt-zoom Web camera mounted on the U.S. Coast Guard tower at

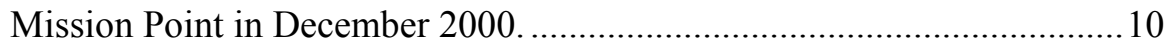

Figure 9. Location of Web cameras and fields of view....................................10

Figure 10. Maximum accumulated freezing degree-days $\left({ }^{\circ} \mathrm{F}\right)$ for Sault Ste.

Marie, Michigan, 1961-2001.................................................................. 11

Figure 11. Accumulated freezing degree-days $\left({ }^{\circ} \mathrm{F}\right)$ for Sault Ste. Marie, Michigan; 1998, 1999, 2000, and 2001 winters compared. ......................12

Figure 12. Winter average outflow from Lake Superior, 1970-2001............... 12

Figure 13. January average water levels in the Soo Harbor, 1940-2001............13

Figure 14. Record of daily average air temperature and wind speed at Chippewa County Airport. 
Figure 15. Surface water velocity distribution in the vicinity of the structures. 15

Figure 16. Sheet ice growing from the eastern shore towards the structures..... 18

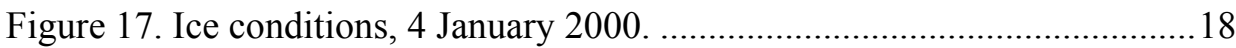

Figure 18. Sheet ice cover to the east, 14 January 2000 ...................................19

Figure 19. Ice conditions, 14 January 2000.................................................... 19

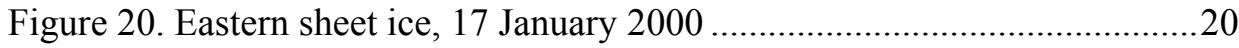

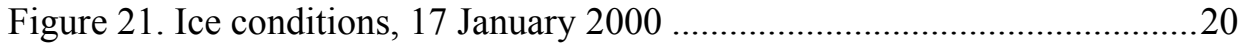

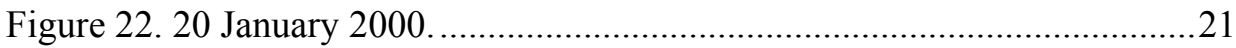

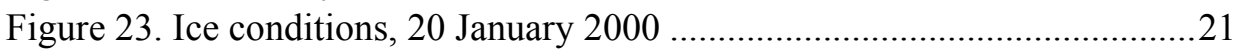

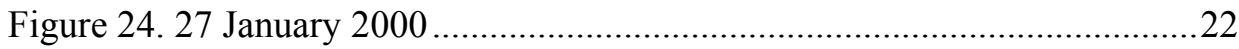

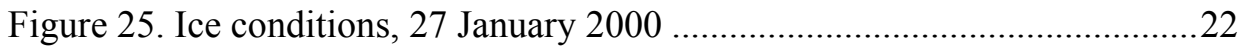

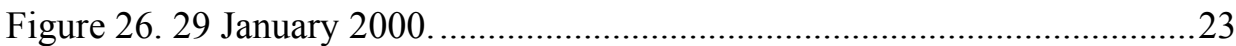

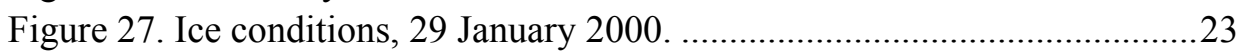

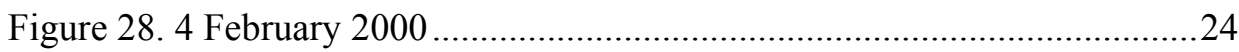

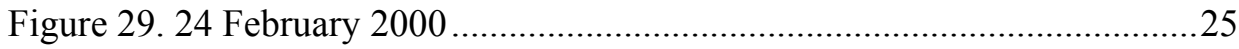

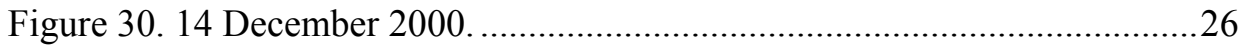

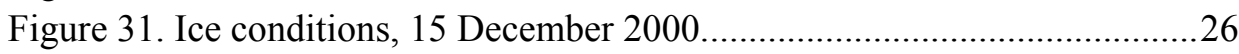

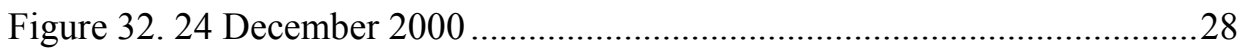

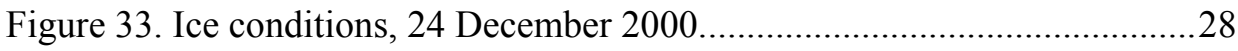

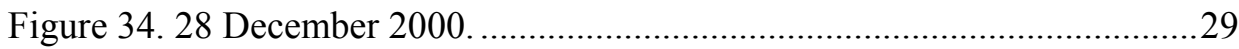

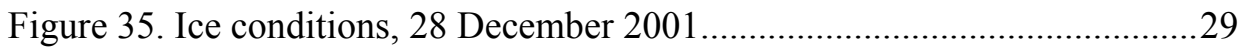

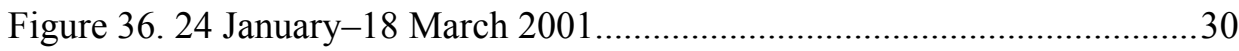

Figure 37. Ice conditions, 24 January-18 March 2001 .....................................30

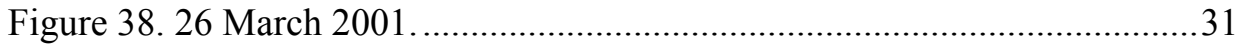

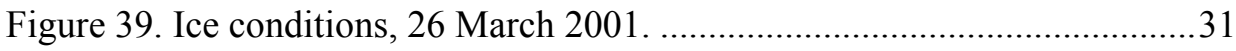

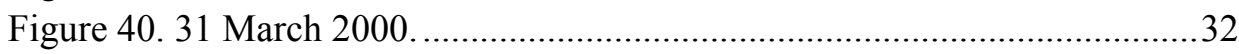

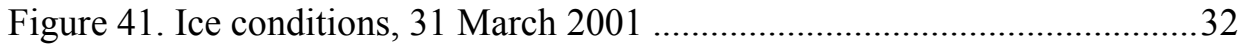

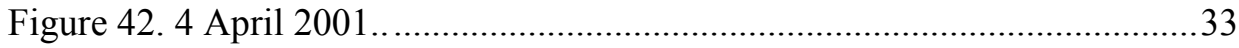

\section{TABLE}

Table 1. Timing of $0^{\circ} \mathrm{C}$ water temperature and stable ice at booms.................... 


\title{
Videomonitoring Performance of the St. Marys River Ice Islands and Ice Boom
}

\author{
ANDREW M. TUTHILL AND JOHN J. GAGNON
}

\section{INTRODUCTION}

Man-made islands and ice booms on the St. Marys River at Sault Ste. Marie, Michigan, reduce ice problems in the Little Rapids Cut and facilitate winter operation of the Sugar Island Ferry. The original boom, first installed in 1974, consisted of two arms with a central navigation opening. In 1997 six rock islands were built to help stabilize the ice cover along the eastern edge of the navigation channel and serve as above-water anchors for the east arm of the ice boom.

The U.S. Army Cold Regions Research and Engineering Laboratory (CRREL), through a contract with the Soo Area Office of the Detroit District, Corps of Engineers, installed Web cameras to monitor the performance of the ice stabilization islands during the 1999-2000 and 2000-2001 winter seasons. The key question to be answered was whether the islands performed well enough by themselves that the boom spans, and their attendant operation and maintenance costs, could be eliminated. This report analyzes the image data and assesses the performance of the islands. 


\section{BACKGROUND}

The St. Marys River is 45 miles long, connecting Lake Superior and Lake Huron (Fig. 1). Lake Superior's average winter outflow is $73,000 \mathrm{cfs}, 70 \%$ of which passes through the Little Rapids Cut. Under normal winter conditions, sufficient ice cover develops in Soo Harbor between late December and midJanuary to form an ice bridge at the head of the cut. Undisturbed, this ice bridge stabilizes the ice cover upstream and prevents ice from moving into the cut. The ice bridge is occasionally disturbed by warming and wind or by vessel traffic. This can destabilize the ice field in Soo Harbor and bring large amounts of broken ice into the cut. As a result of the Great Lakes-St. Lawrence Seaway Navigation Season Extension Program, which began in 1971, the ice bridge at the head of Little Rapids Cut was continuously breached by ship traffic. The increased ice movement into the cut frequently halted or interfered with ongoing ferry operations between Sugar Island and the mainland, blocked the navigation channel, and increased the frequency of ice jams in the lower Little Rapids Cut.

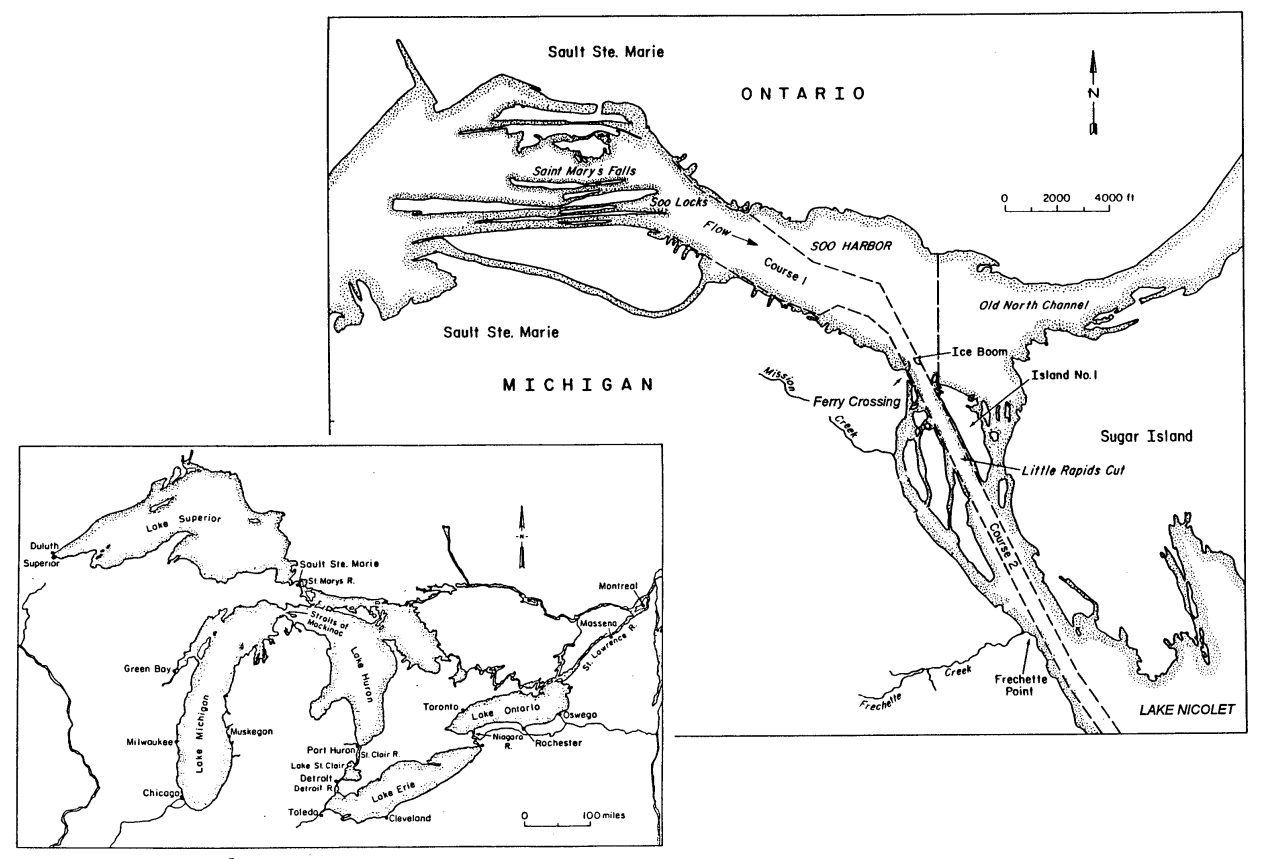

Figure 1. Project location.

As a result, in 1974, the Detroit District of the Corps of Engineers contracted Acres American Incorporated to conduct a physical hydraulic model study to 
develop concepts for ice restraint (Acres American Inc. 1975, Cowley et al. 1977). The goals of the study were to help stabilize the ice cover in Soo Harbor, moderate ice problems in the cut, and generally aid winter navigation. The study recommended an ice boom with an opening for navigation, which was designed by the Detroit District with assistance from CRREL. The boom was first installed in December 1975 and, because of its effectiveness, has been installed annually since then. Perham (1978) documents the boom's performance during its first two seasons.

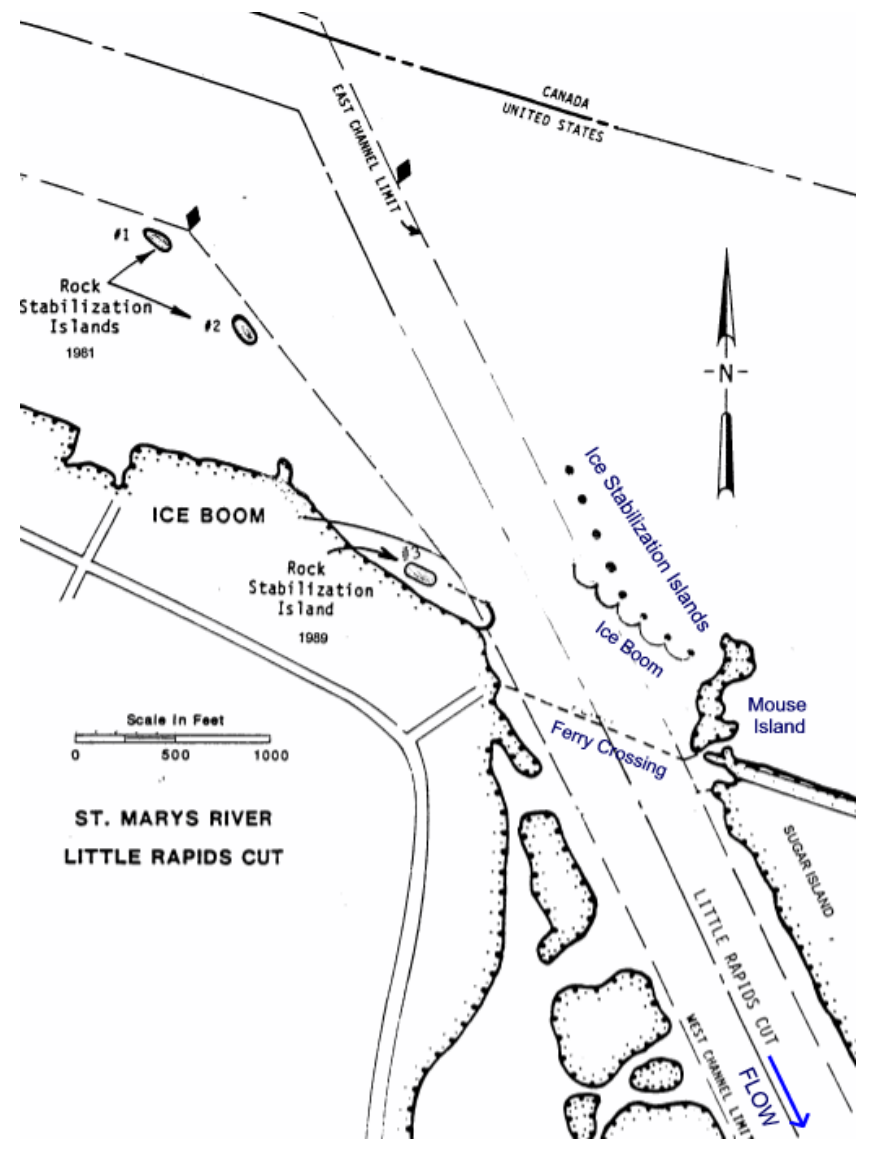

Figure 2. Project area.

The original ice boom consisted of $1-\mathrm{ft} \times 2-\mathrm{ft} \times 20$ - $\mathrm{ft}$ timbers and had two arms with a central navigation opening of $250 \mathrm{ft}$ (Fig. 2). A number of modifications have improved performance and reliability. These include the construction of three rock islands in the 1980s to stabilize the sheet ice along the west side of the channel after a large floe detached from the shore and damaged the western arm of the boom. In 1989, two H-piles were driven on the east side of the channel 
to simplify boom installation. The H-piles suffered ice damage and were later built into rock islands. Also in 1989, one of the western boom spans was eliminated, widening the gap to $375 \mathrm{ft}$ to improve navigability. In April 1995, after the navigation season had begun and the ice had gone out on the Soo Harbor, a snowstorm and strong easterly winds drove snow slush against the east arm of the boom, resulting in the failure of several anchor cables. The damaged boom moved into the navigation channel, jeopardizing shipping, and was removed with some difficulty.

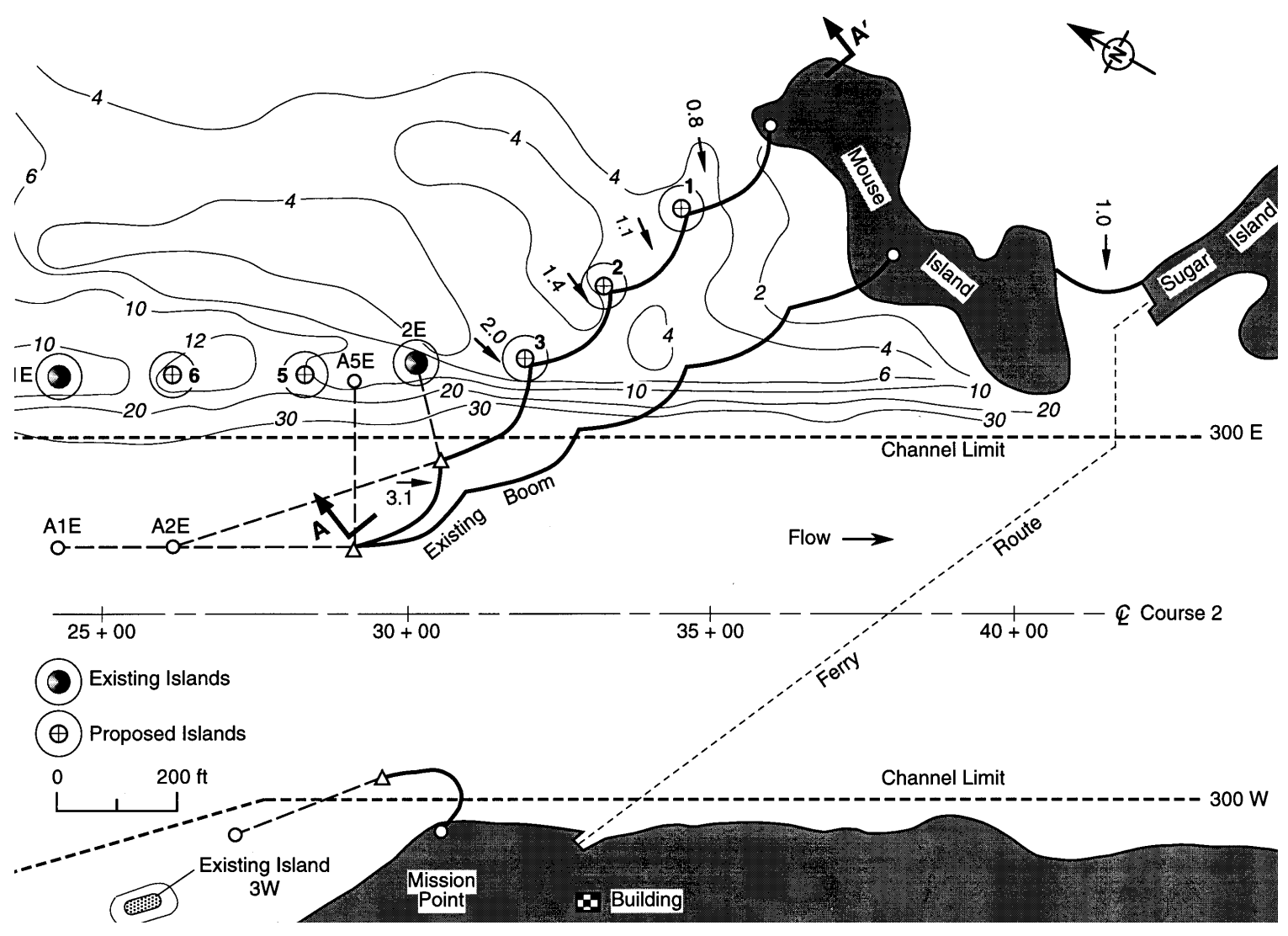

Figure 3. Recommended alternative from the 1996 study.

Because of the ongoing costs and risks associated with ice boom installation and maintenance, in 1996, the Soo Area Office contracted with CRREL to examine options for replacing the boom, or portions of it, with permanent structures, such as rock islands. Tuthill and Carey (1996) investigated the performance history of the boom and estimated the change in ice discharge into the Little Rapids Cut that would result from replacing the east arm of the boom with 
a series of artificial islands. They concluded that relying solely on the islands (with no boom spans) would likely increase the ice discharge into the cut to unacceptable levels for the Sugar Island Ferry. The study predicted that using the islands in conjunction with boom spans would improve the stability of the sheet ice on the eastern side of the navigation channel, and would protect the boom from excessive loadings from wind-driven slush or large floes. The islands would also provide above-water anchors for boom spans, simplifying installation.

Figure 3 shows the recommended alternative. The study suggested that, after observing the performance of the islands over several ice seasons, it might be feasible to eliminate some of the boom spans. The islands were built in 1997 and six boom spans were installed. Figure 4 shows the project in December 2000 with only five spans installed. There is no boom between Mouse Island and the first island.

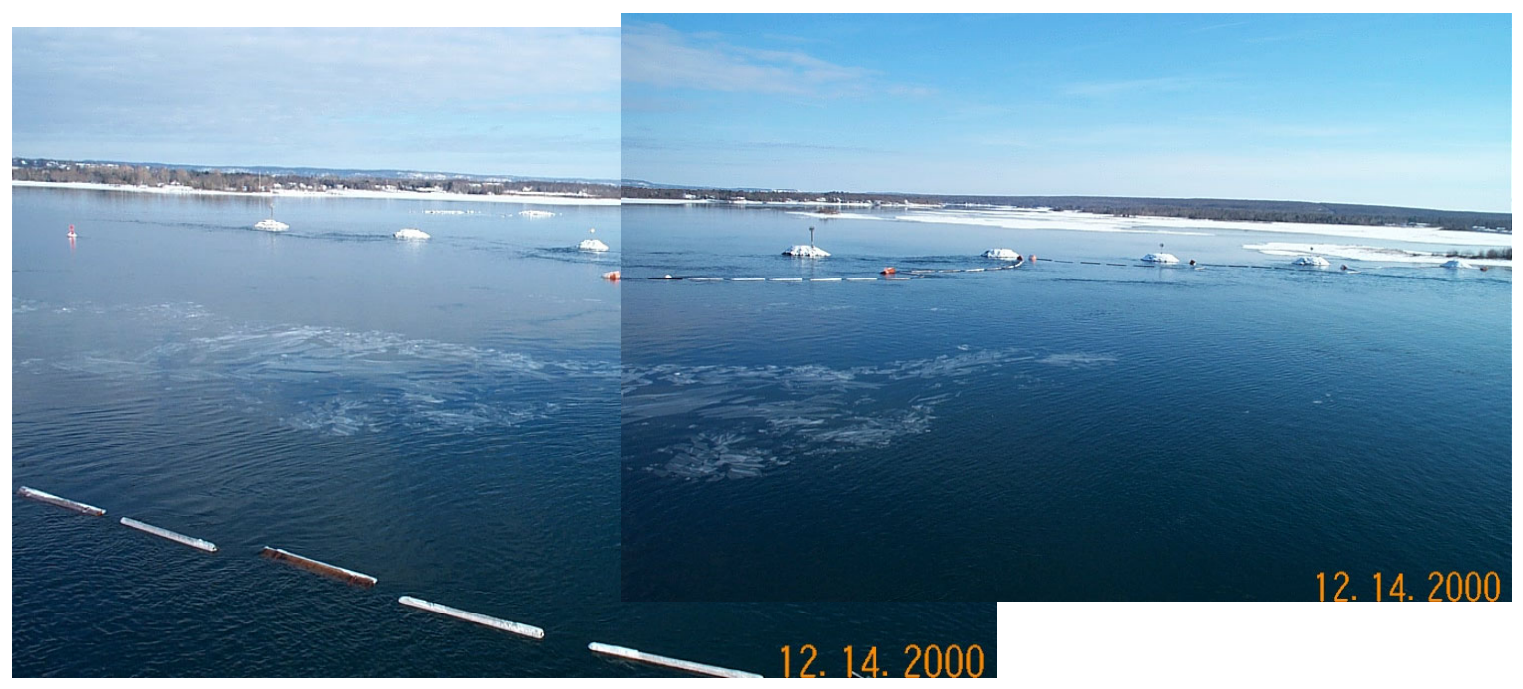

Figure 4. Completed ice stabilization islands and east arm of ice boom, December 2000. 


\section{ICE REGIME ON THE ST. MARYS RIVER AND ICE BOOM PERFORMANCE}

The following description of the ice formation process is based on review of the St. Marys River Ice Boom Annual Report series maintained by the Detroit District from 1976 to 1992 . The most important period in terms of ice discharge into the Little Rapids Cut occurs between mid-December and mid-to-late January, when the ice cover is forming in Soo Harbor. Figure 5 shows that, in much of the St. Marys River upstream of the Little Rapids Cut, the water velocity is on the order of $1 \mathrm{ft} / \mathrm{s}$, allowing sheet ice growth out from the shores. Frazil and thin plate ice form in the central, higher velocity areas between St. Marys Falls and the entrance to the Little Rapids Cut. When this drifting ice reaches the cut entrance, where the water velocity is in the 2- to-3-ft/s range, the ice either stops behind the two arms of the boom or passes through the 375 -ft-wide navigation opening. The ice that moves into the cut collects initially against the sheet ice cover on Lake Nicolet, then progresses upstream within the cut to form a shoved ice accumulation 1.5 to $3 \mathrm{ft}$ thick. In the 1971-1994 period, the ice cover reached the Sugar Island Ferry Crossing nine times.

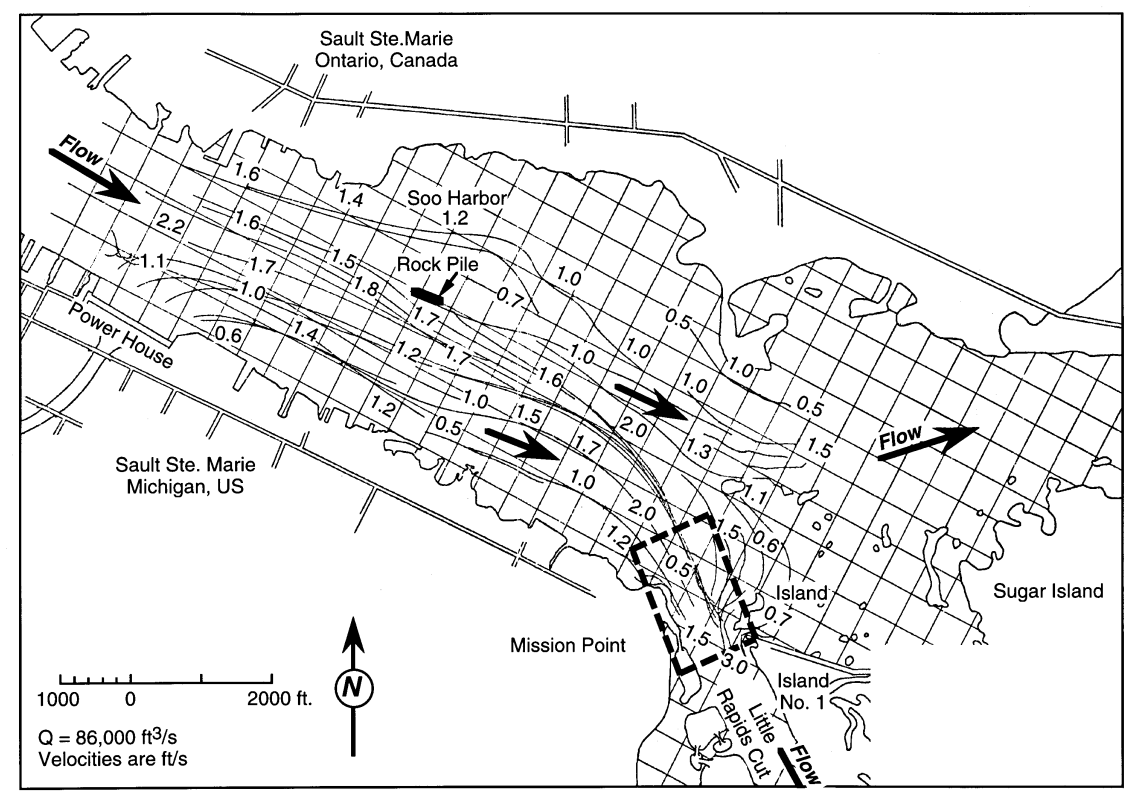

Figure 5. Water velocity on the St. Marys River upstream of Little Rapids Cut, from Acres American (1975) drogue study with a total river flow of 86,000 cfs. 
If air temperature is consistently low, the loose accumulations of frazil and small floes consolidate upstream of the boom arms and form stable ice fields. The formation of stable ice behind the booms coincides fairly well with the date that the Lake Superior outflow reaches $0^{\circ} \mathrm{C}$, which, on average, occurs by the first week in January (Table 1). A stable ice bridge across the entire opening forms about three weeks later and usually marks the start of a stable midwinter period. Lacking a major thaw or frequent vessel activity, ice discharge into the cut and ice cover progression are minimal after this time. Thaw periods can delay the formation of a stable ice cover at the entrance of the Little Rapids Cut and can weaken the upstream ice cover. If thaws are followed by strong northwesterly winds, heavy ice discharges into the cut result.

\begin{tabular}{|c|c|c|}
\hline $\begin{array}{c}\text { Winter } \\
\text { (water year) }\end{array}$ & $\begin{array}{c}\text { First day of } 0^{\circ} \mathrm{C} \\
\text { water temperature }\end{array}$ & $\begin{array}{c}\text { Date of first stable ice } \\
\text { at booms }\end{array}$ \\
\hline 1976 & 10 January 1976 & 10 January 1976 \\
\hline 1977 & 12 December 1976 & 1 January 1977 \\
\hline 1978 & 30 December 1977 & 13 December 1977 \\
\hline 1979 & 30 December 1978 & 28 December 1978 \\
\hline 1980 & 10 January 1980 & 9 January 1980 \\
\hline 1981 & 18 December 1980 & 18 December 1981 \\
\hline 1982 & 3 January 1982 & 2 January 1982 \\
\hline 1983 & 27 January 1983 & January 1983 \\
\hline 1984 & 27 December 1983 & 5 January 1984 \\
\hline 1985 & 26 December 1984 & 26 December 1984 \\
\hline 1986 & 20 December 1985 & 18 December 1985 \\
\hline 1987 & 20 January 1987 & 20 January 1987 \\
\hline 1988 & 5 January 1988 & 21 December 1987 \\
\hline 1989 & 10 January 1989 & 7 January 1989 \\
\hline 1990 & 5 January 1990 & 21 December 1989 \\
\hline 1991 & 10 January 1991 & 7 January 1991 \\
\hline 1992 & 20 January 1992 & 15 January 1992 \\
\hline \multicolumn{3}{|l|}{ 1993-1999 } \\
\hline 2000 & About 14 January & 17 January \\
\hline 2001 & & 28 December \\
\hline Average & 4 January & 7 January \\
\hline
\end{tabular}




\section{INSTALLATION OF WEB CAMERAS}

Two Web cameras were installed by CRREL in December 1999: the first near the top of the 210-ft-high Tower of History two miles northwest of the site in Sault Ste. Marie (Fig. 6) and the second on the U.S. Coast Guard tower at Mission Point, located on the west side of the Little Rapids Cut (Fig. 7). The Tower of History camera was connected to the Internet via direct phone line. During the 1999-2000 winter, the Mission Point camera was connected to the Web via modem and cellular phone.

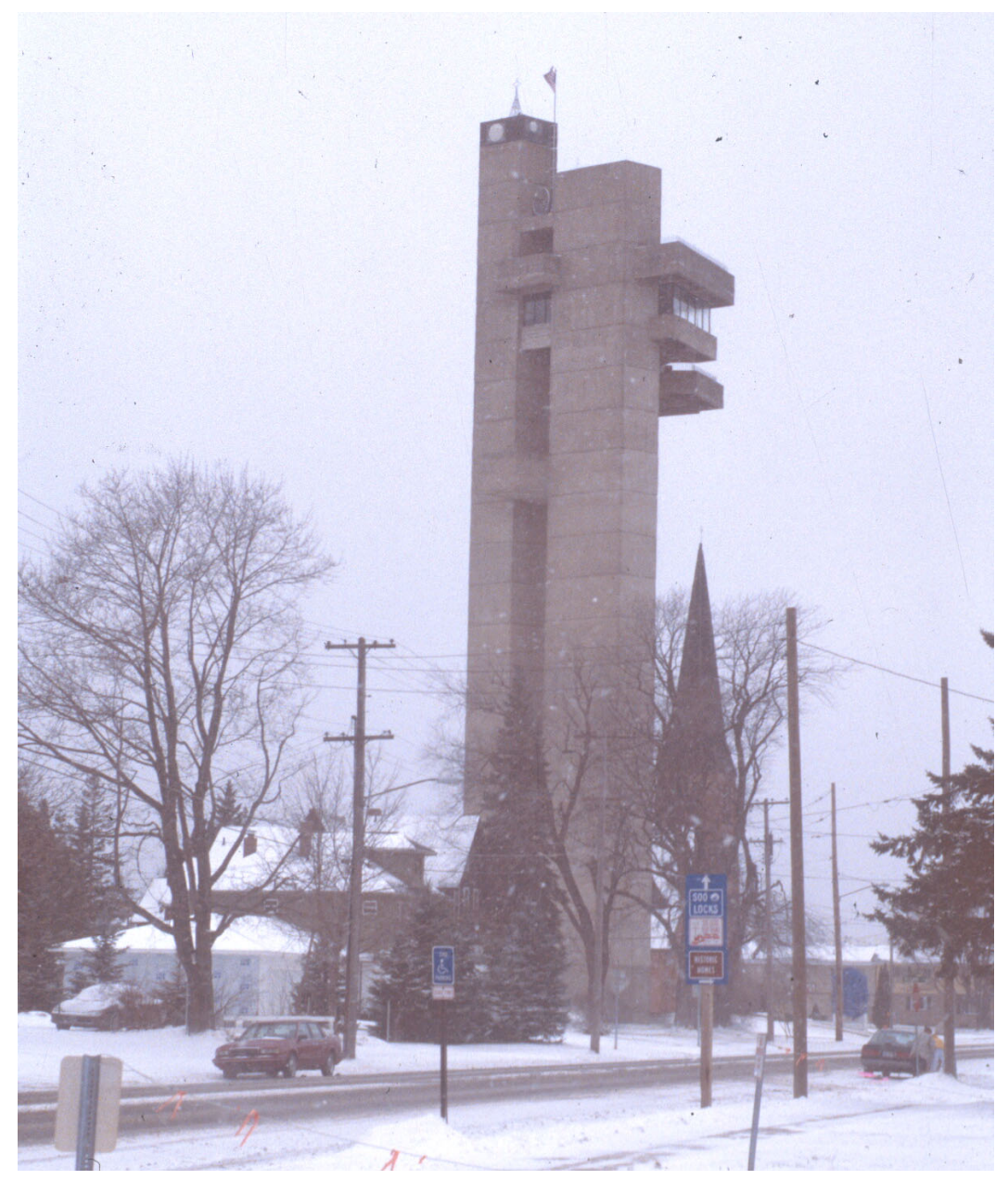

Figure 6. Sault Ste. Marie's 210-ft-high Tower of History, site of Webcam 1. 


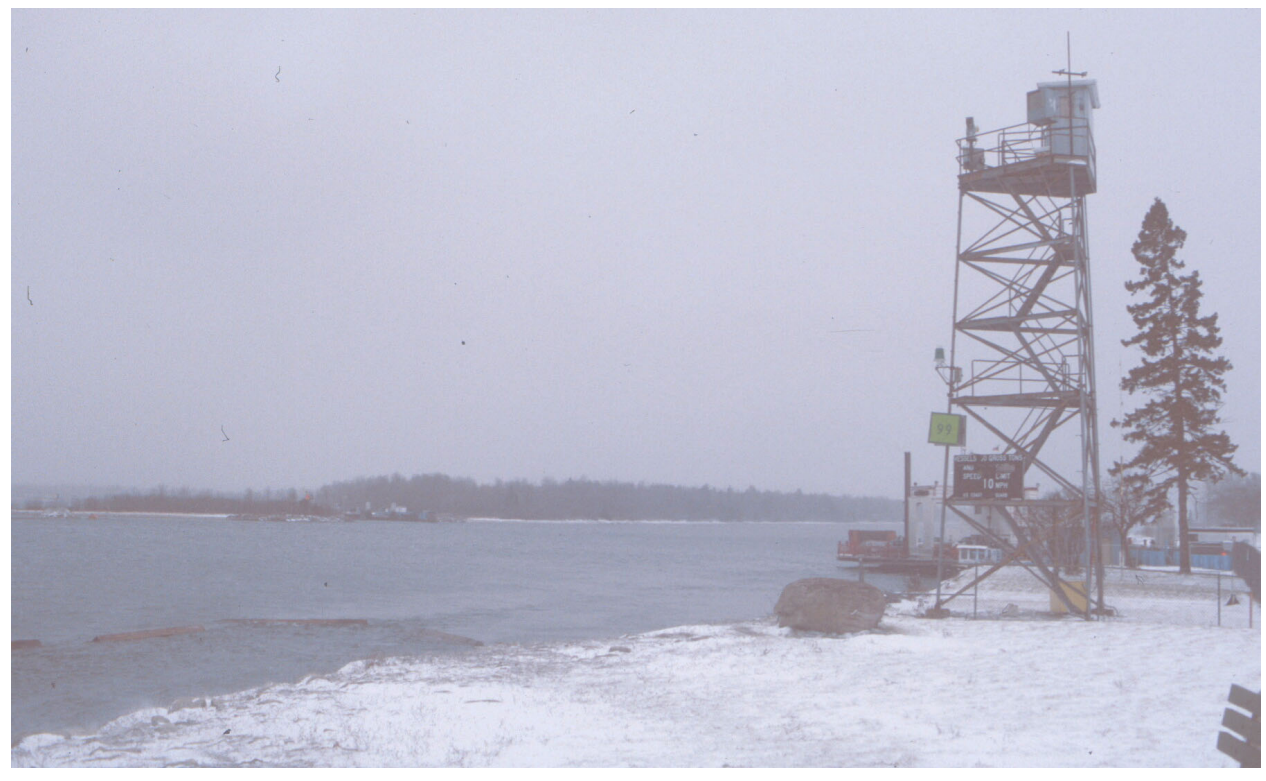

Figure 7. Tower at Mission Point, site of second Webcam and U.S. Coast Guard video camera. The west arm of the boom is on the left and the Sugar Island Ferry slip appears in the background.

In December 2000, a pan-tilt-zoom camera replaced the fixed camera at Mission Point (Fig. 8) and three additional cameras were added to provide a $100^{\circ}$ field of view extending from the ferry slip to the most upstream island. Instead of relying on a cellular phone, a wireless Ethernet radio modem sent image data to a Web server located two miles away at the Soo Locks. Figure 9 shows the camera locations and fields of view. The Tower of History camera gave a good overall view of the islands and the area to the east while the Mission Point cameras provided detailed images of the ice stabilization islands and boom spans. In addition to the Web cameras, during the 1999-2000 winter, the U.S. Coast Guard agreed to record video of any interesting ice conditions or significant changes in the ice conditions at the Little Rapids Cut using their pan-tilt-zoom video camera at Mission Point. The Coast Guard video data proved invaluable because of its wide field of view and particularly after the cellular phone system connected to the Mission Point Web camera failed after 11 January 2000.

Every 15 minutes, each camera sent a JPEG image file to CRREL for display on the CRREL Web page. 


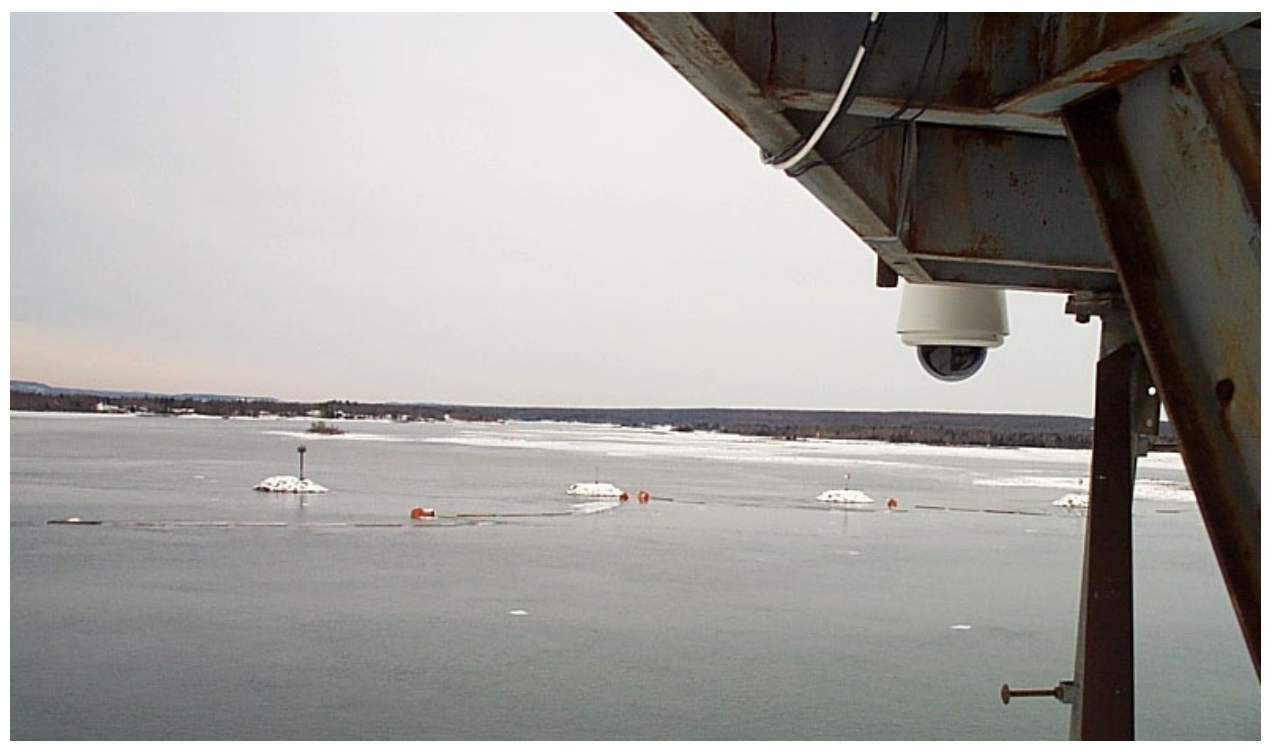

Figure 8. Pan-tilt-zoom Web camera mounted on the U.S. Coast Guard tower at Mission Point in December 2000.

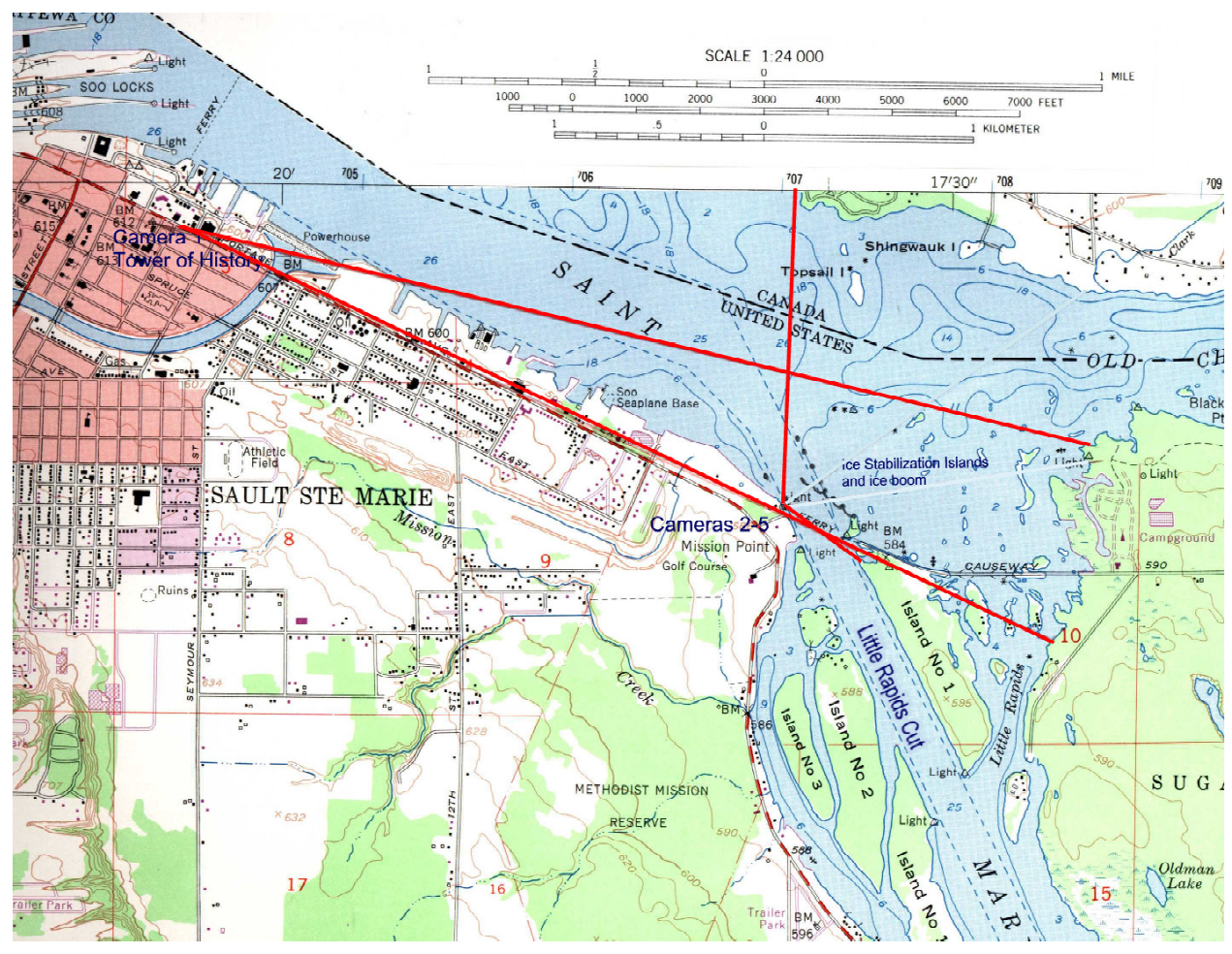

Figure 9. Location of Web cameras and fields of view. 


\section{FACTORS AFFECTING ICE COVER FORMATION AND RECENT TRENDS}

The winters since the ice stabilization islands were built in 1997 have been relatively mild. Accumulated freezing degree days (AFDD) are a good overall indicator of the severity of a winter and are often used to estimate the thickness of the ice formed on rivers and lakes. For the winters ending in 1998, 1999, 2000, and 2001, the maximum AFDDs were 972, 1209, 1081, and $1520^{\circ} \mathrm{F}$-days, respectively, compared to the average maximum AFDD of $1731^{\circ} \mathrm{F}$-days for Sault Ste. Marie (Fig. 10).

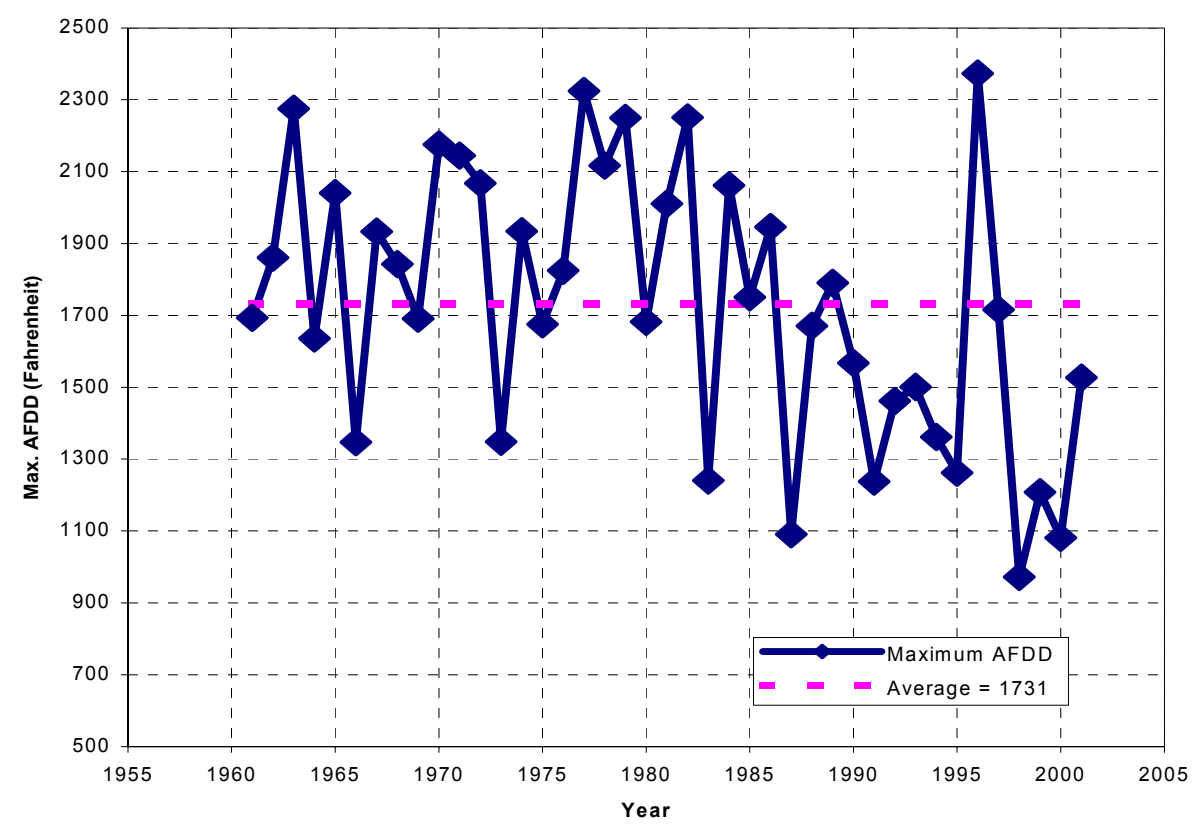

Figure 10. Maximum accumulated freezing degree-days $\left({ }^{\circ} \mathrm{F}\right)$ for Sault Ste. Marie, Michigan, 1961-2001.

According to local reports, no significant ice formed on the Soo Harbor during the winters of 1998 and 1999. Although the winter of 2000 was similar in coldness to the previous two, an ice cover and an ice arch formed upstream of the Little Rapids Cut by 20 January, and it remained in place for almost a month. Contributing factors were the persistent cold between mid-December and midFebruary, as well as below-average discharge and water levels on the St. Marys River (Fig. 11-13). The winter of 2000-2001 was colder overall than the pre- 
vious winter, and, although ice covers formed on both sides of the navigation channel upstream of the cut entrance, a complete ice arch never formed across the channel. A possible explanation is the lack of an extreme cold spell in 2001, similar to the one that occurred in January 2000 (Fig. 14).

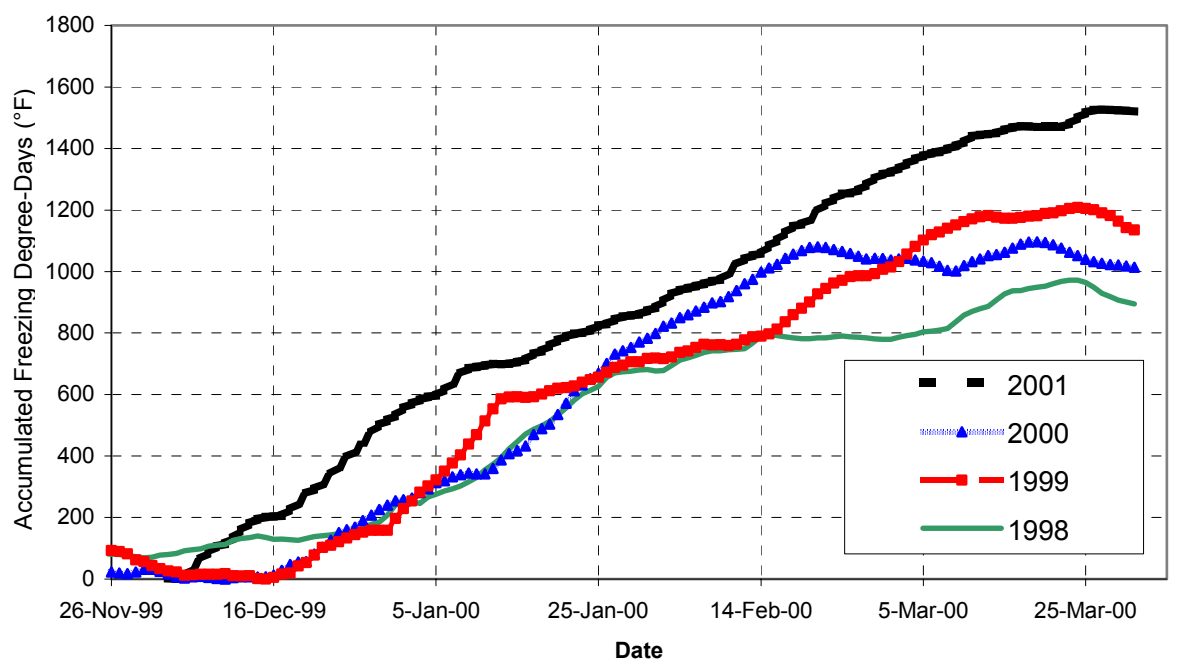

Figure 11. Accumulated freezing degree-days $\left({ }^{\circ} F\right)$ for Sault Ste. Marie, Michigan; 1998, 1999, 2000, and 2001 winters compared.

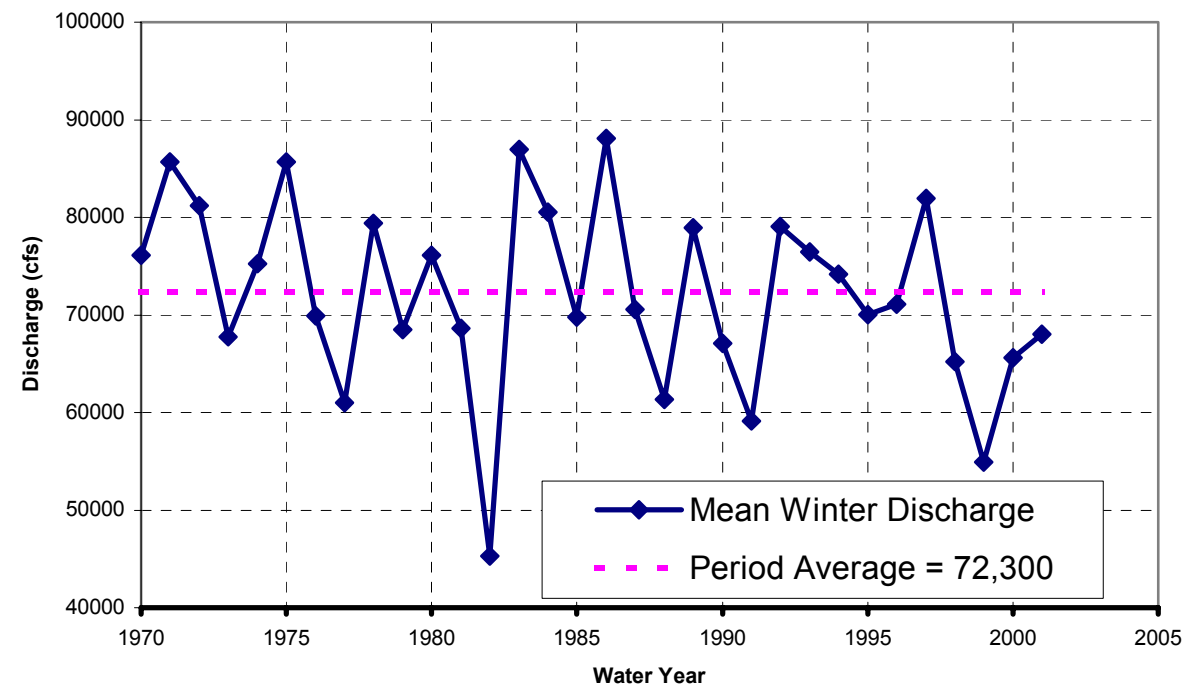

Figure 12. Winter average outflow from Lake Superior, 1970-2001. 


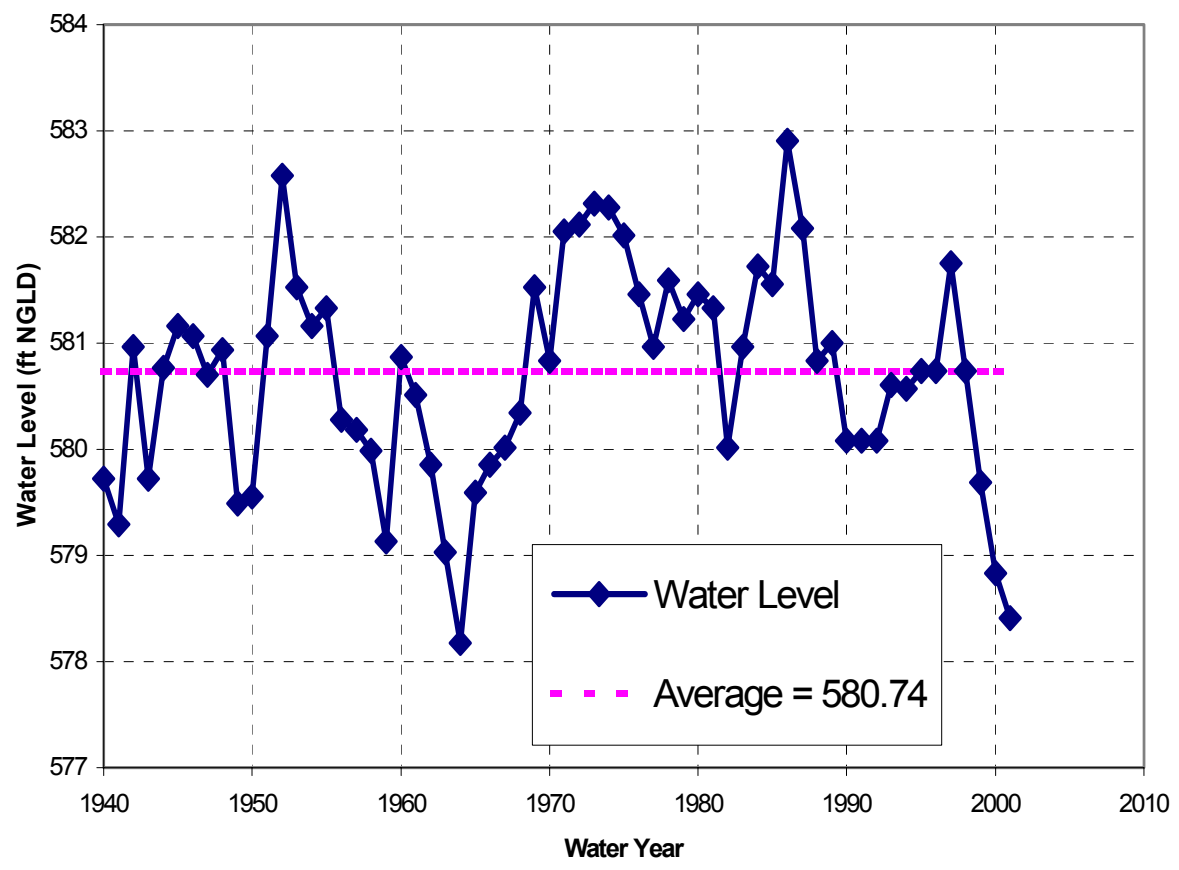

Figure 13. January average water levels in the Soo Harbor, 1940-2001.

Other important factors in the ice formation processes are surface water velocity (Fig. 5 and 15) and wind speed (Fig. 14). An accepted rule of thumb is that an ice boom will retain ice if water surface velocity is at or below about 2.5 $\mathrm{ft} / \mathrm{s}$ (U.S. Army 1999). The measured data in Figure 15 indicate that ice retention behind boom spans 4 and 5 (counting from right to left) is marginal and the image data support this. With strong winds from the north, ice would typically pass beneath these outer spans. The inner three spans, where water velocity is less than $2 \mathrm{ft} / \mathrm{s}$, were almost always capable of retaining ice. In the gap between Island 1 and Mouse Island, where water velocity was on the order of $1 \mathrm{ft} / \mathrm{s}$, sheet ice formed with no boom span in place. 


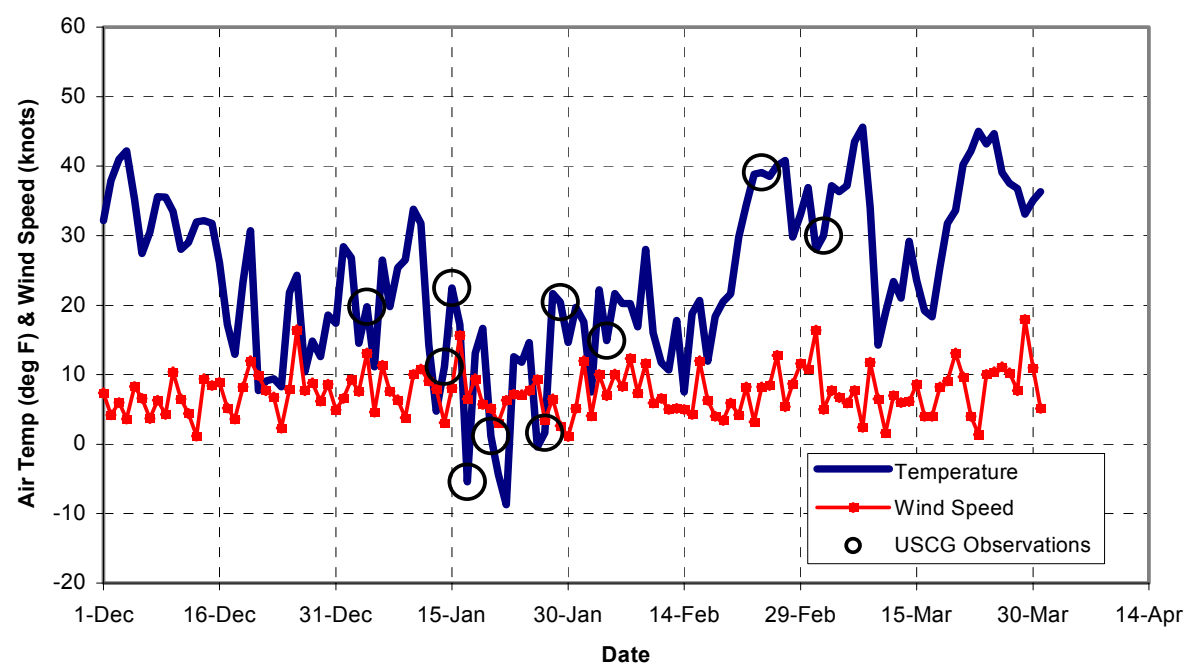

a. Winter of 1999-2000.

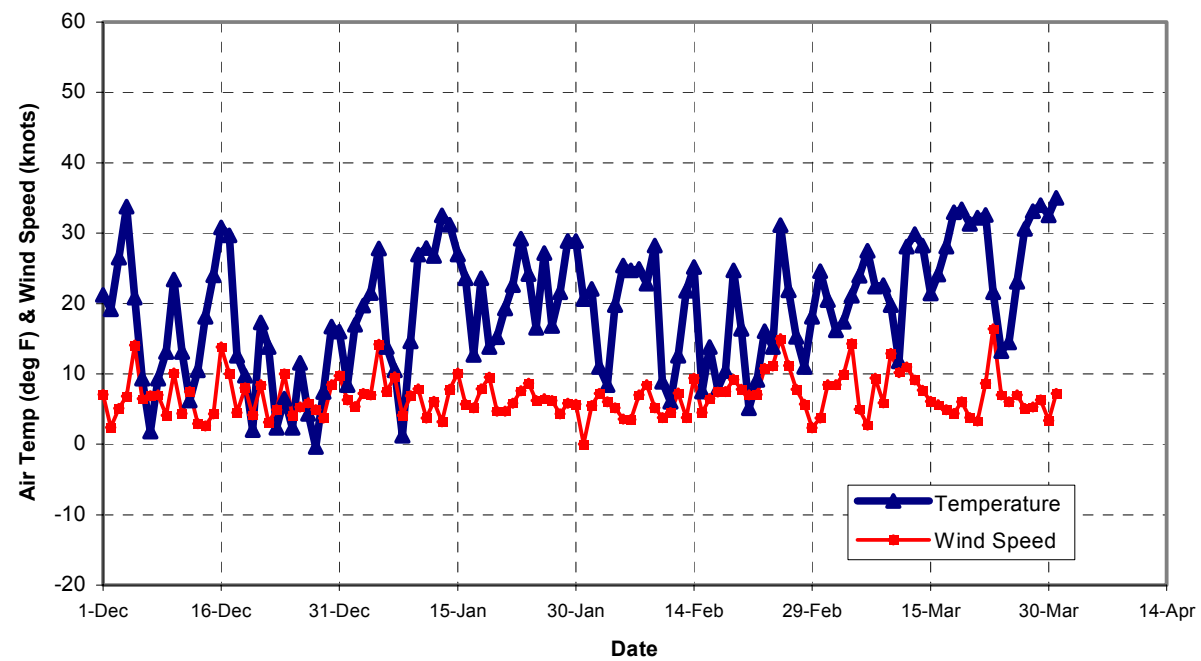

b. Winter of 2000-2001.

Figure 14. Record of daily average air temperature and wind speed at Chippewa County Airport, near Sault Ste. Marie, Michigan. 


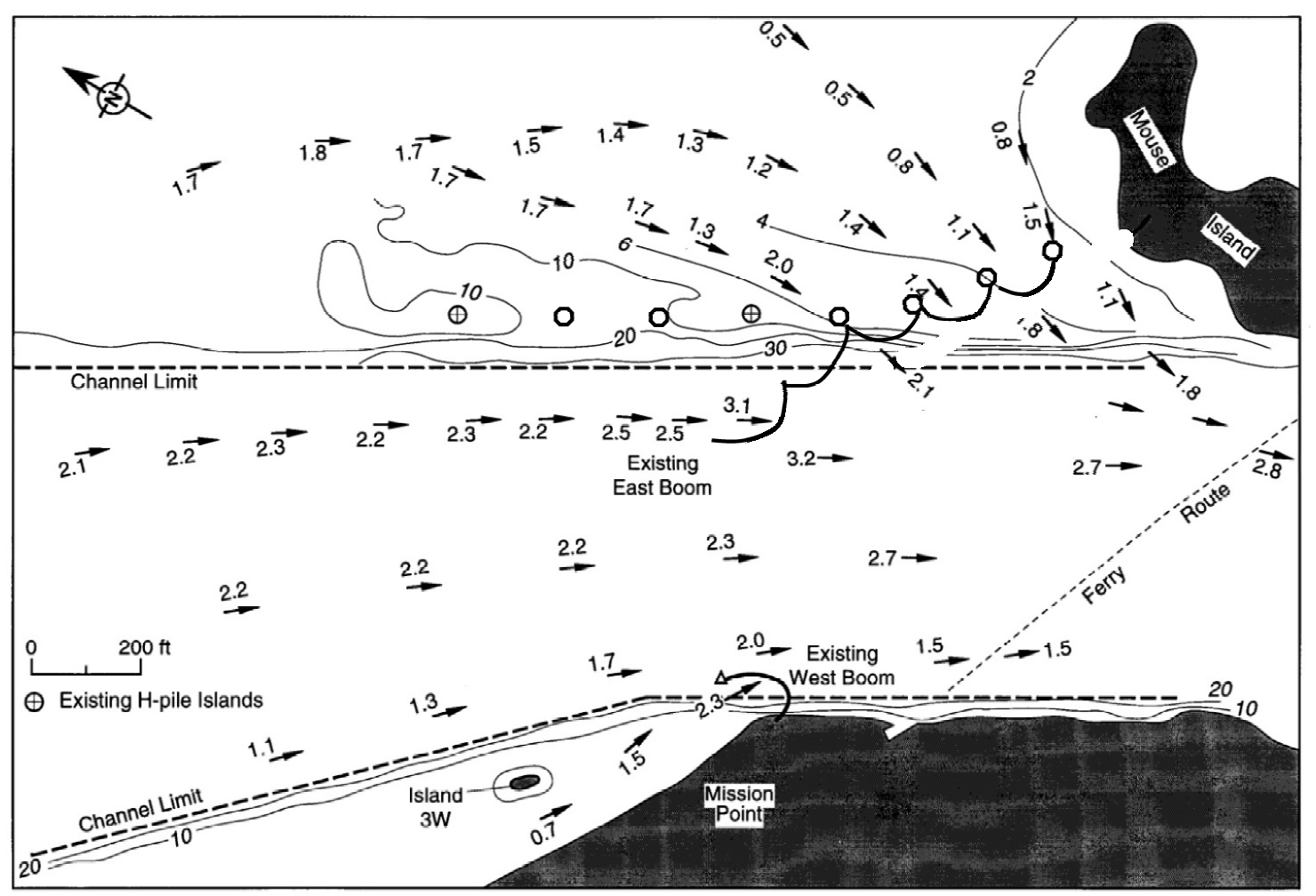

Figure 15. Surface water velocity distribution in the vicinity of the structures, from Acres American (1975) drogue study with a total river flow of 86,000 cfs. 


\section{OBSERVATIONS}

The following descriptions of ice cover formation and breakup are based on a series of Web camera images from the Tower of History and Mission Point and also detailed video footage from the Mission Point Coast Guard video camera. Animations composed of daily images from the Web cameras can be viewed at http://www.crrel.usace.army.mil/permanent/sooislands/.

\section{Winter 1999-2000}

By mid-December 1999, daily average air temperatures at Sault Ste. Marie were consistently at or below the freezing point, and sheet ice had begun forming in the shallow, low-velocity areas along the shores of the St. Marys River upstream of the Little Rapids Cut. By late December, the sheet ice to the northeast of the Little Rapids Cut extended from the north end of Sugar Island to about halfway to the ice stabilization islands. The mid-channel area with higher water velocity and more mixing remained ice-free until the outflow from Lake Superior had cooled to very near the freezing point. Records from the U.S.Coast Guard indicate that the $0^{\circ} \mathrm{C}$ water temperature occurred by about 14 January 1999 , compared to an average date of 7 January for the 1976-1992 period (Table 1).

By 4 January 2000 , the sheet ice area to the north of Sugar Island extended to within several hundred yards of the islands (Fig. 16 and 17), and boom spans 1, 2 , and 3 were retaining small fields of unconsolidated frazil. Open water still existed behind the eastern islands and Mouse Island, and a narrow band of shore ice lined the west bank upstream of Mission Point. Average air temperature for 4 January was relatively mild $\left(20^{\circ} \mathrm{F}\right)$ and strong northerly winds were pushing floes and frazil slush under boom spans 4 and 5 (Fig. 17). Disperse floes up to $15 \mathrm{ft}$ in diameter could be seen drifting down both margins of the navigation channel and into the cut.

Between 4 and 14 January 2000, daily average air temperature had decreased significantly (Fig. 14a) and Soo Harbor water temperature had reached the freezing point. The sheet ice to the north of Sugar Island extended nearly to the line of islands with a narrow lead interrupting the cover behind and to the north of Mouse Island (Fig. 18 and 19). Average air temperature for 14 January was $11^{\circ} \mathrm{F}$, winds were relatively calm, and large fields of frazil slush the width of the navigation channel were drifting into the cut. Stable ice existed behind boom spans 1,2, and 3 and the eastern portion of span 4. Island 4, which is upstream of span 4, appeared to be helping stabilize the ice. The Sugar Island Ferry was moving easily through the moving ice fields, indicating that the frazil was thin 
and unconsolidated. On 15 January, average air temperature increased to $22^{\circ} \mathrm{F}$, and no flows or moving frazil slush were in evidence.

By 17 January 2000, a stable ice sheet covered the entire area from the north end of Sugar Island to the edge of the navigation channel, surrounding the islands (Fig. 20 and 21). Sheet ice also extended out from the west shore to the edge of the navigation channel, surrounding the three west-side ice stabilization islands. 17 January was extremely cold $\left(-7^{\circ} \mathrm{F}\right)$. Massive frazil slush floes were moving into the cut, nearly arching across the gap. The ferry was able to easily negotiate the floes, indicating that they were relatively thin and unconsolidated.

By 20 January 2000, a stable ice arch had formed across the navigation channel about $4000 \mathrm{ft}$ upstream of the boom. Although 20 January was extremely cold $\left(0^{\circ} \mathrm{F}\right)$, the upstream ice arch prevented all but minor ice floes from drifting into the cut (Fig. 22 and 23).

Between 20 and 27 January 2000 daily average air temperatures warmed to the teens for three days, then cooled back to $1^{\circ} \mathrm{F}$. Wind action on 26 January caused large floes to break from the sheet ice arch and lodge in the channel constriction adjacent to the boom spans and islands by 27 January (Fig. 24 and 25). Ice rubble between the floes and the stationary ice on the west side of the channel indicated that shearing had occurred.

By 29 January 2000, the open leads between the floes and the upstream arch had frozen over. Air temperature had moderated $\left(20^{\circ} \mathrm{F}\right)$ and the sheet ice had a slightly gray, decayed appearance (Fig. 26). Much broken ice and ice rubble was interspersed between the floes lodged in the entrance to the cut (Fig. 27). Ice rubble zones were visible between the floes, especially where the floes had sheared along the stationary ice bordering the navigation channel.

Between 29 January and 4 February 2000, daily average air temperatures were in the teens to low 20s and a continuous lead eroded through the ice cover upstream of the cut, following the approximate path of the fastest water velocity from the 1975 drogue study (Fig. 5). The islands appeared to help retain the sheet ice on the east side of the lead. A small lead also appeared adjacent to the middle island on the west side of the channel (Fig. 28). Air temperatures remained cold until the third week of February, which marked the start of a three-week-long thaw with daily average air temperatures in the $30-40^{\circ} \mathrm{F}$ range. 


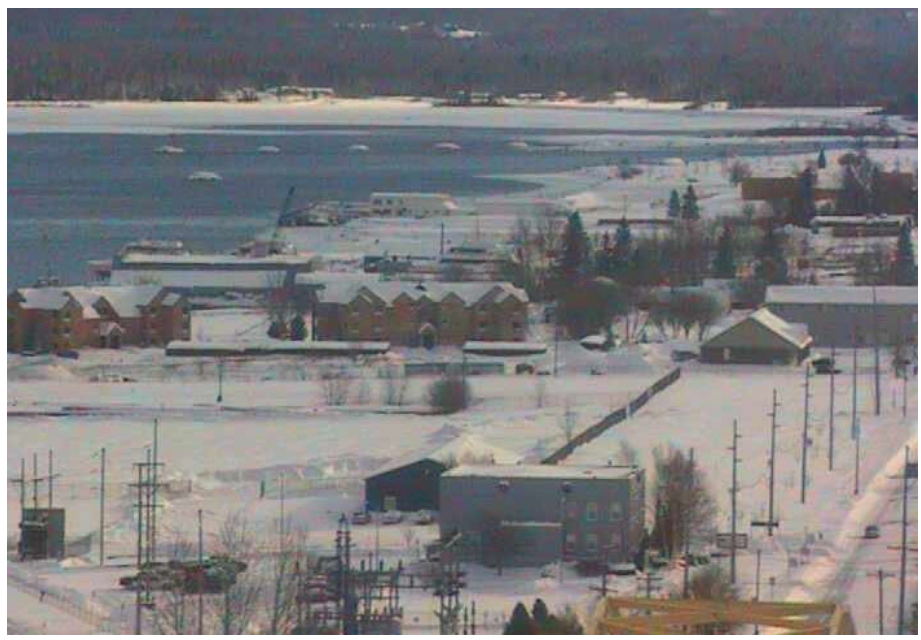

Figure 16. Sheet ice growing from the eastern shore towards the structures, 4 January 2000.

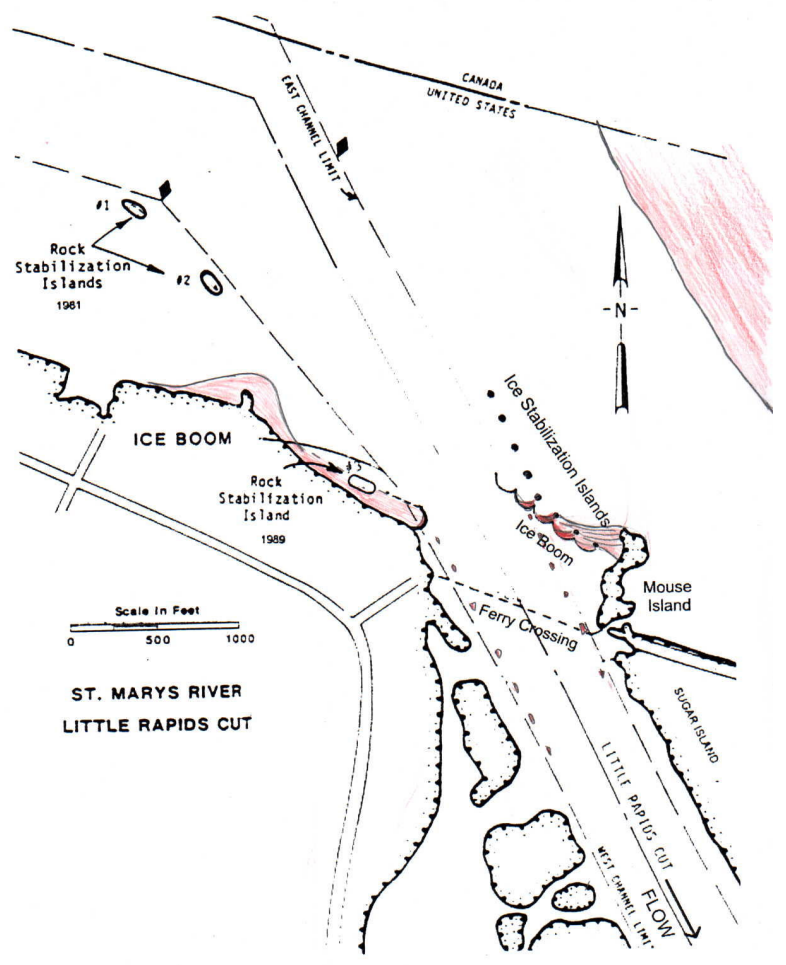

Figure 17. Ice conditions, 4 January 2000, with ice forming behind boom spans 1,2 , and 3 , and small floes drifting into cut. 


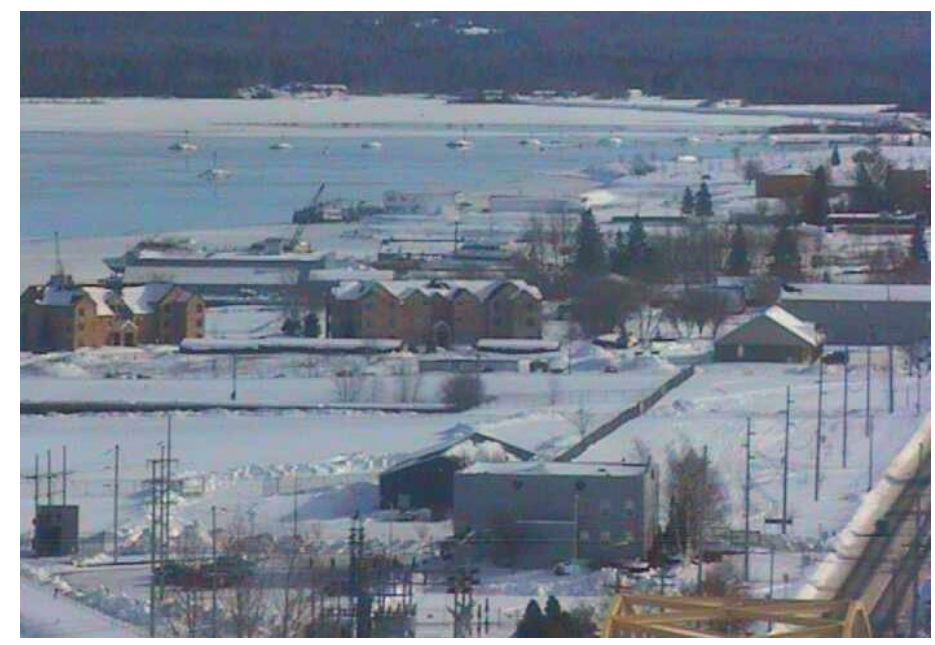

Figure 18. Sheet ice cover to the east, 14 January 2000. This cover extends nearly to the islands.

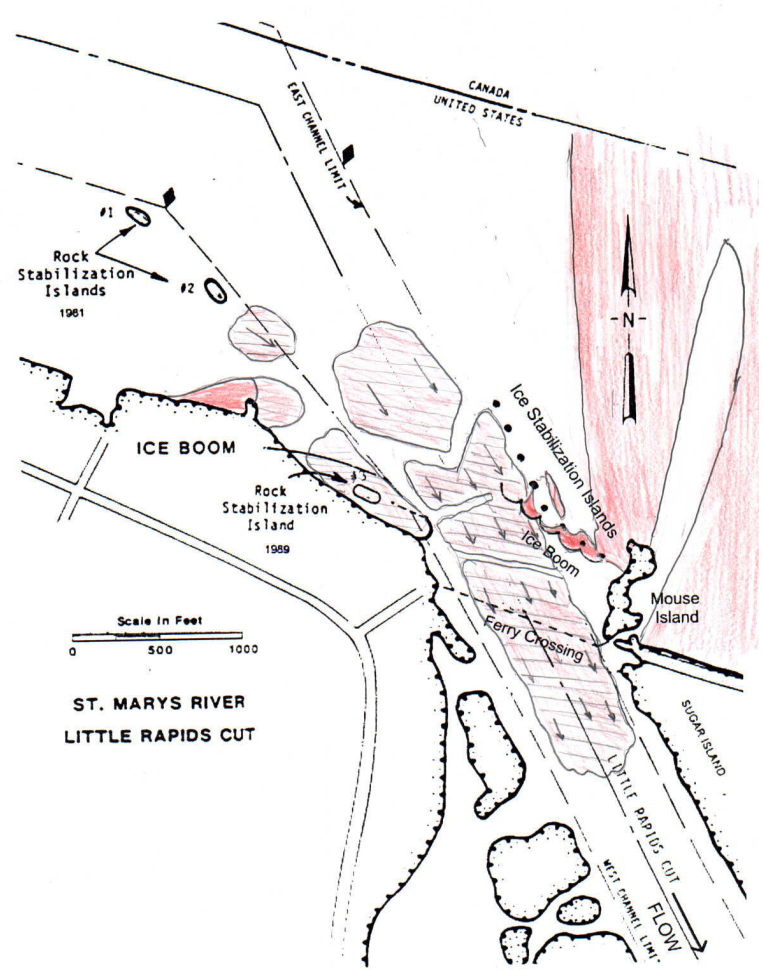

Figure 19. Ice conditions, 14 January 2000, with ice forming behind boom spans $1-4$, and large frazil floes drifting into cut. 


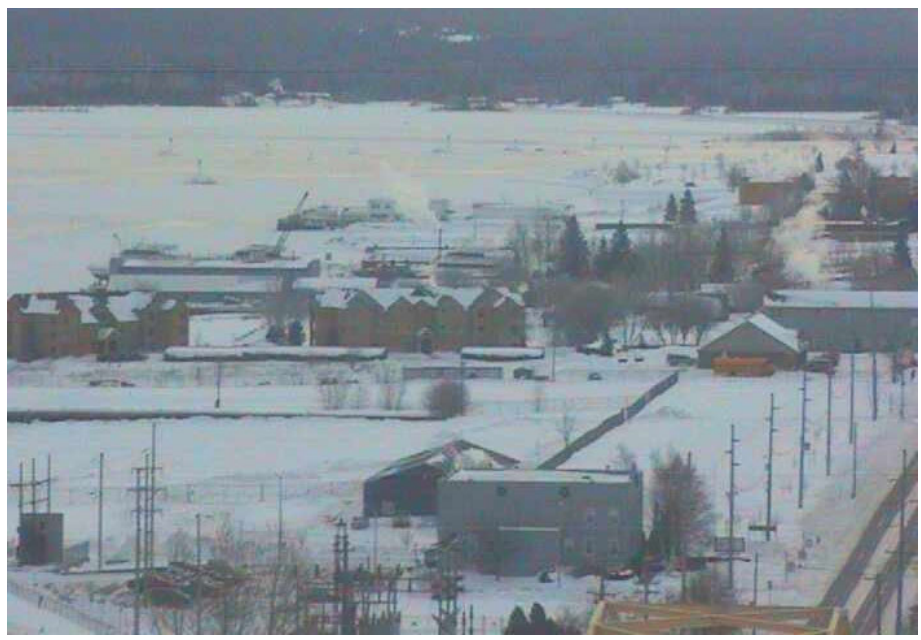

Figure 20. Eastern sheet ice, 17 January 2000. This sheet ice extended beyond the islands to the edge of the navigation channel.

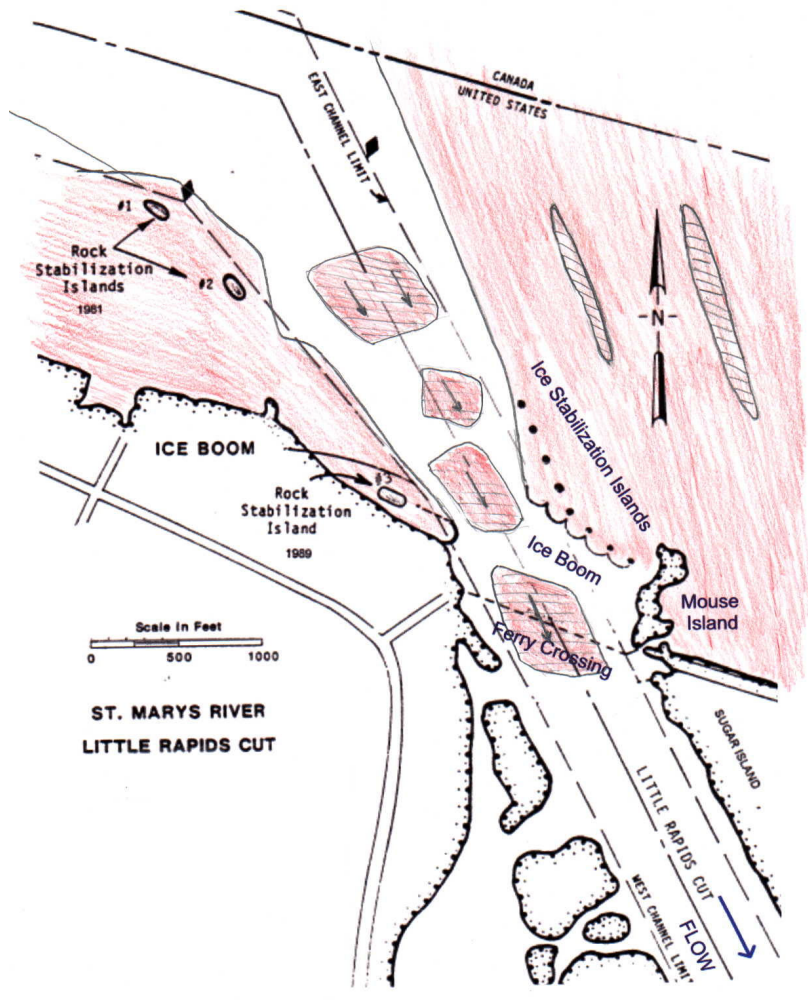

Figure 21. Ice conditions, 17 January 2000, with ice behind all boom spans and around islands, and large frazil floes drifting into cut. 


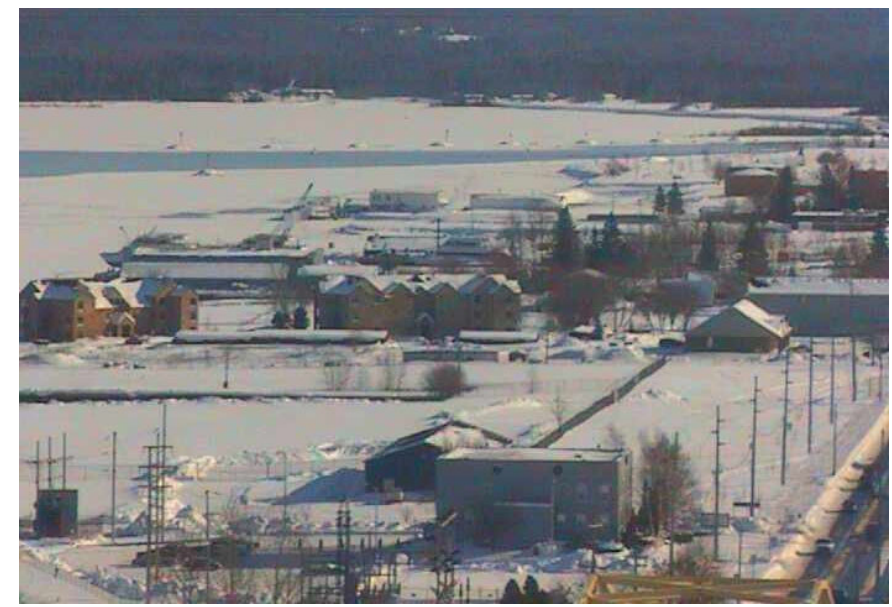

Figure 22. 20 January 2000. By this date, an ice arch had formed upstream of the Little Rapids Cut.

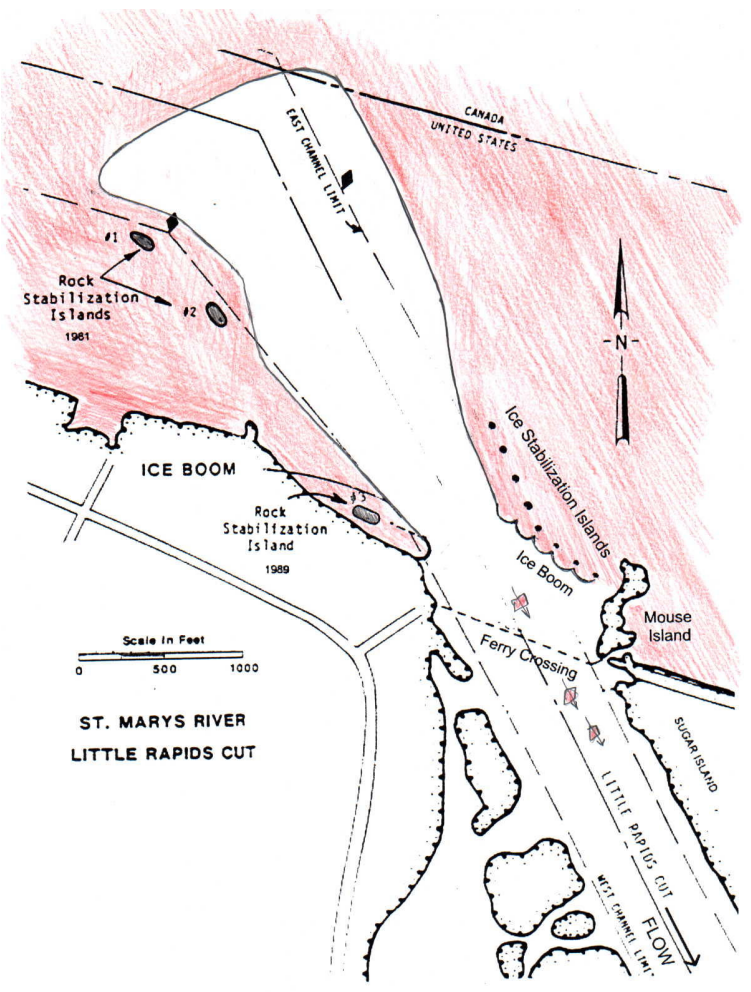

Figure 23. Ice conditions, 20 January 2000, with ice behind all boom spans and around islands. The formation of an ice arch upstream limits the quantity of ice floes entering the cut. 


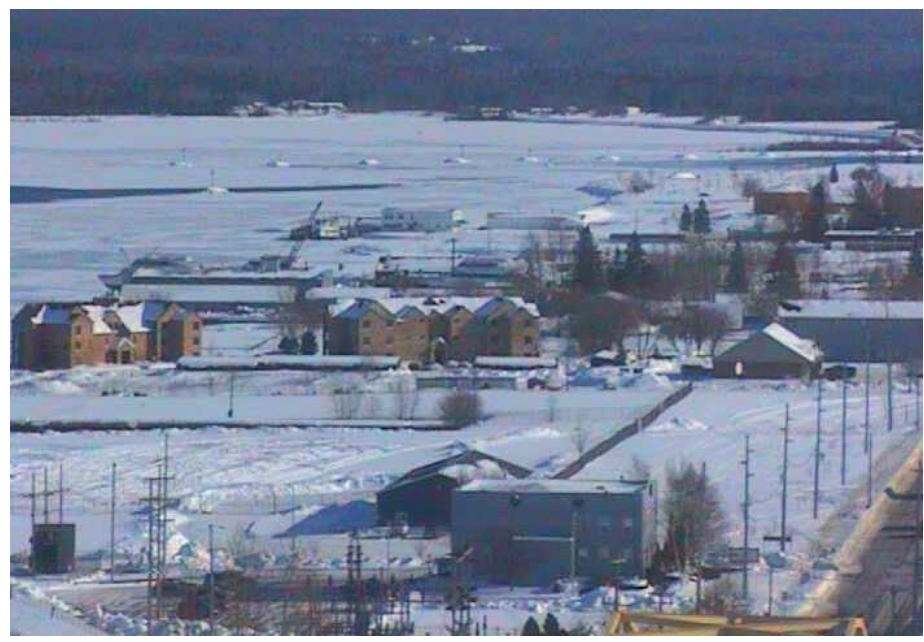

Figure 24. 27 January 2000. By this date, large floes had broken from the upstream sheet ice cover and lodged in the entrance to the cut.

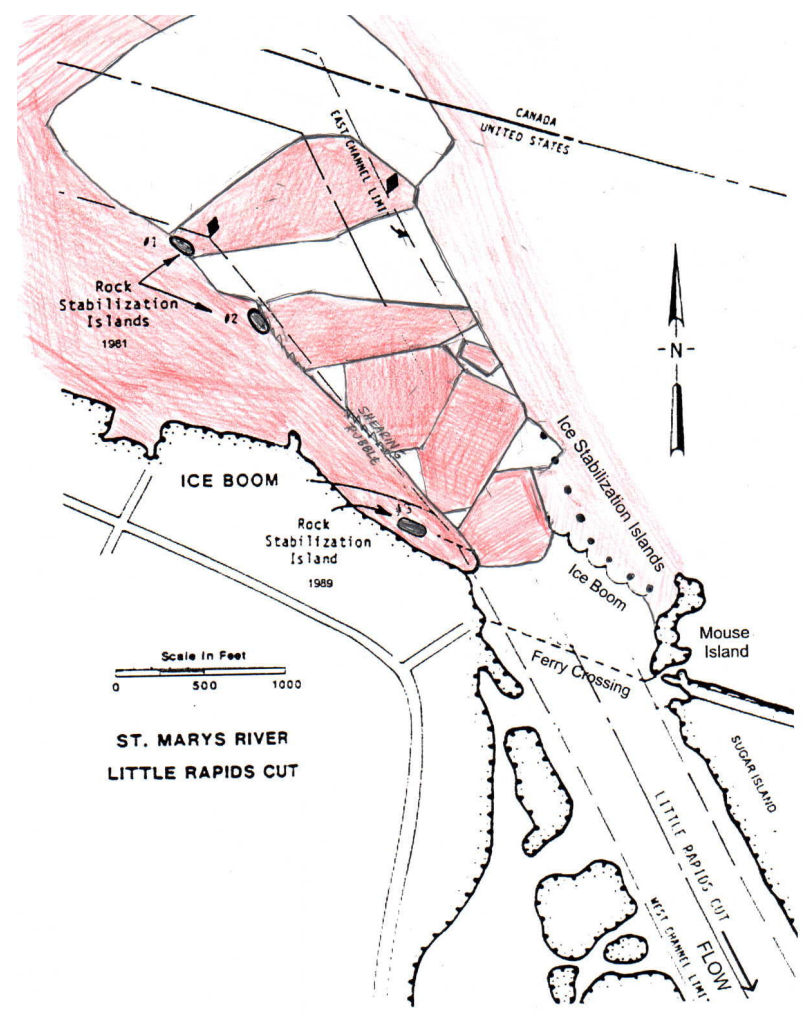

Figure 25. Ice conditions, 27 January 2000. Ice pieces lodged in the constriction between the arms of the ice boom. 


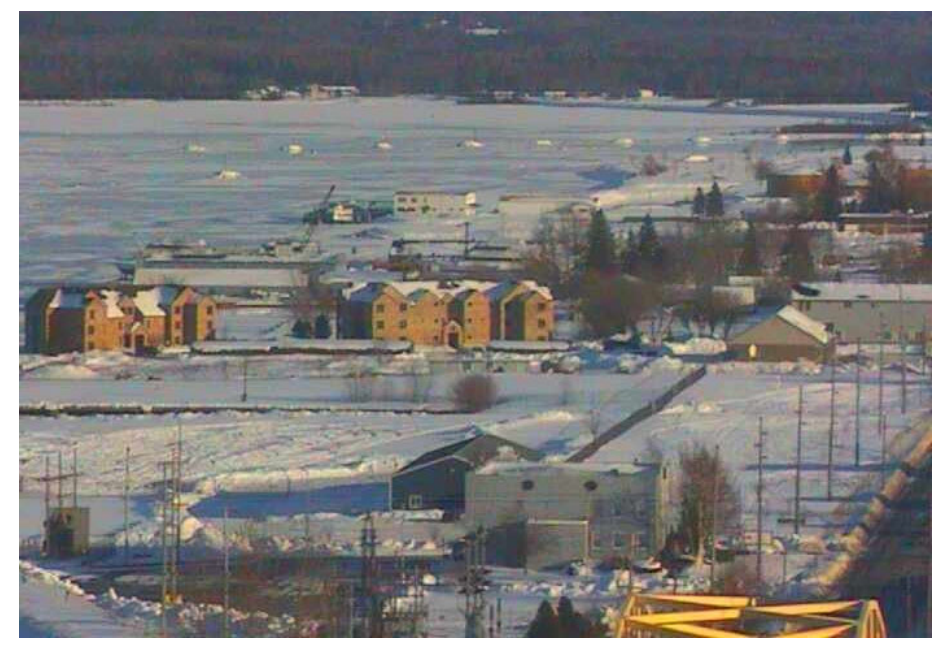

Figure 26. 29 January 2000. Many of the leads upstream of the boom had closed in.

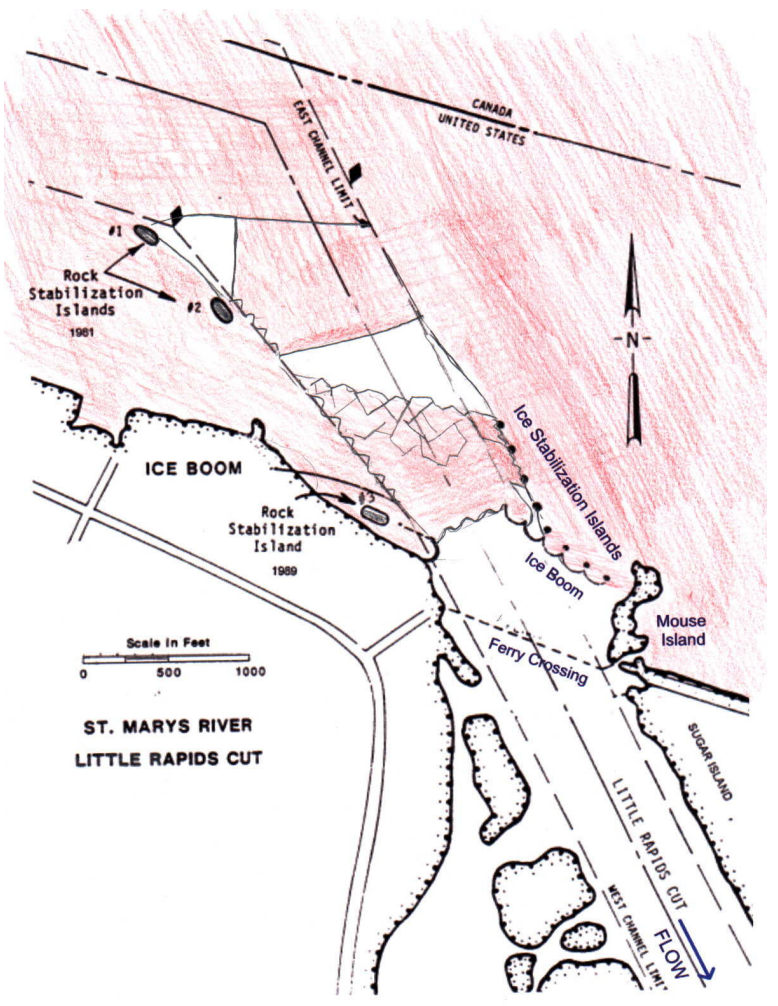

Figure 27. Ice conditions, 29 January 2000. 


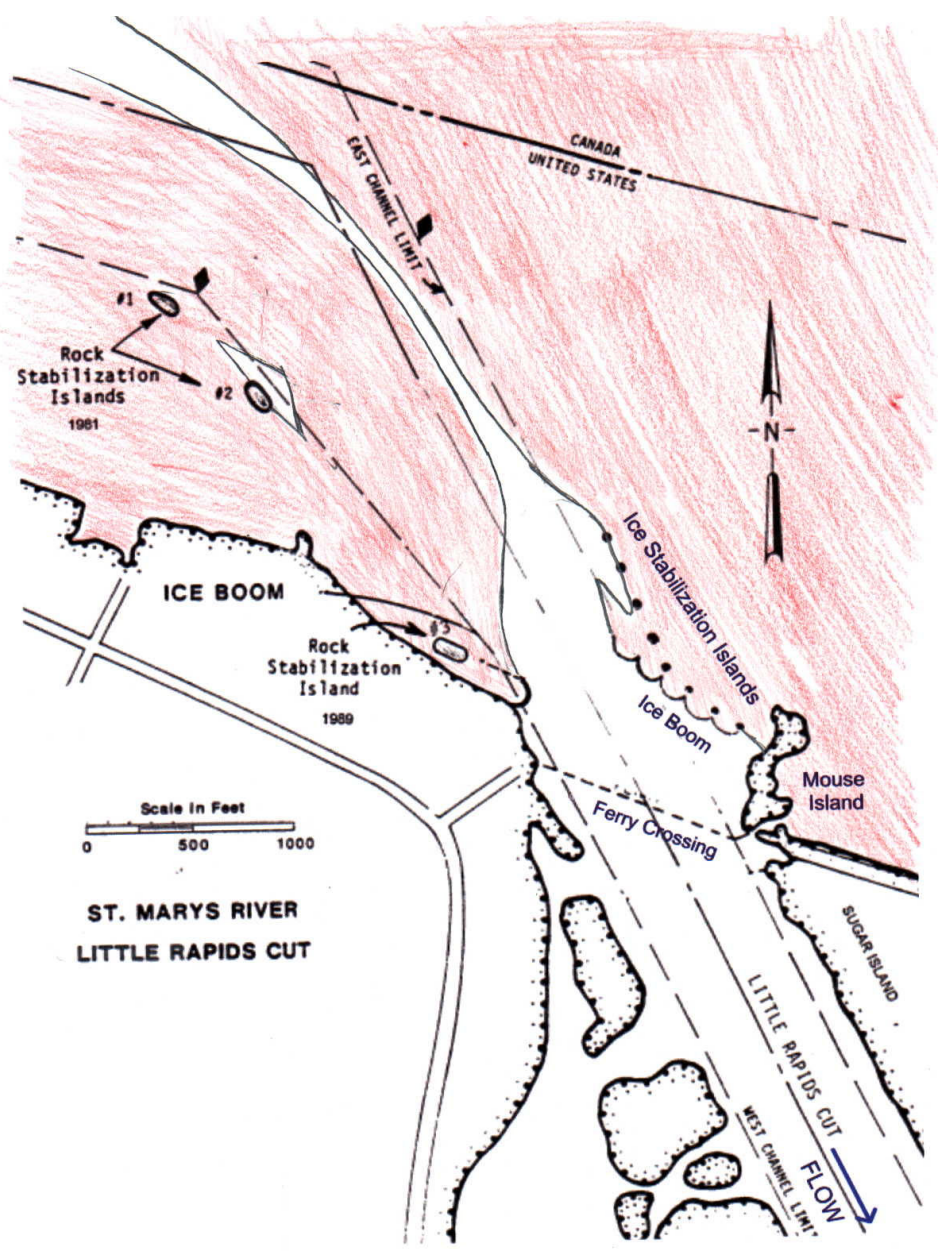

Figure 28. 4 February 2000. A continuous lead had eroded along the path of the highest water velocity.

By 24 February 2000, the ice cover upstream of the Little Rapids Cut had broken up. The Coast Guard video from that day shows nearly all the ice gone, with accumulations of broken sheet ice and floes extending several thousand $\mathrm{ft}$ upstream of Mouse Island and boom spans 1, 2, 3, and 4. Floes and broken sheets also lined the western side of the navigation channel, and a loose arch had formed between the two arms of the boom (Fig. 29).

Although a brief return to colder air temperatures in early March caused a thin ice cover to re-form over much of the river area upstream of the cut, by 17 March 2000, all but the shallow area near the north end of Sugar Island was icefree. 


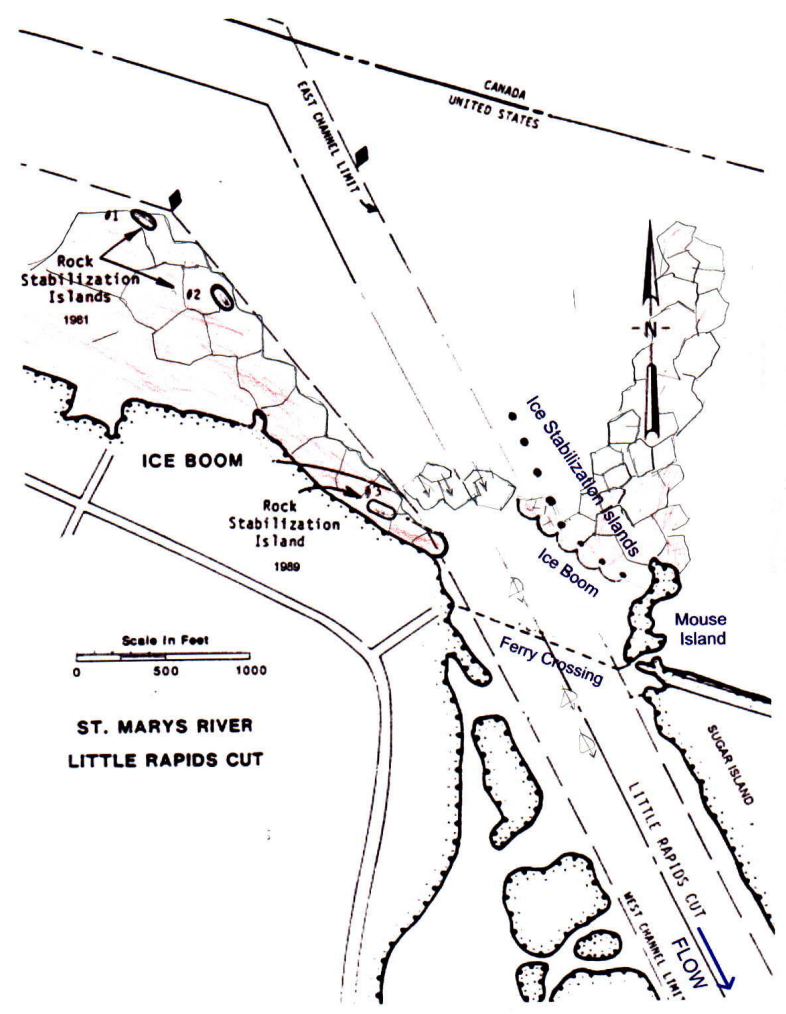

Figure 29. 24 February 2000. Most of the ice upstream of Little Rapids Cut had gone out. Ice floes were retained behind Islands 1, 2, 3, and 4.

\section{Winter 2000-2001}

Similar to the previous year, the fall and winter of 2000-2001 were characterized by below-average water levels and discharges on the St. Marys River (Fig. 12 and 13). Both these factors normally favor the rapid formation of a stable ice cover. Although the winter of 2000-2001 was closer to average in terms of air temperature (Fig. 11), large fluctuations in temperature were less common and there were no periods of extended cold similar to that of January 2000 (Fig. 14). The lack of an extended cold spell may explain why the ice never arched across the entrance to the Little Rapids Cut during the winter of 2000-2001.

By 14 December 2000 , following a week of subfreezing air temperature, a sheet ice cover extended about $3000 \mathrm{ft}$ out from the northwest shore of Sugar Island. An ice cover was building on the northern end of Mouse Island and a spit of ice had formed upstream, running parallel to the sheet ice edge to the east (Fig. 30 and 31). 


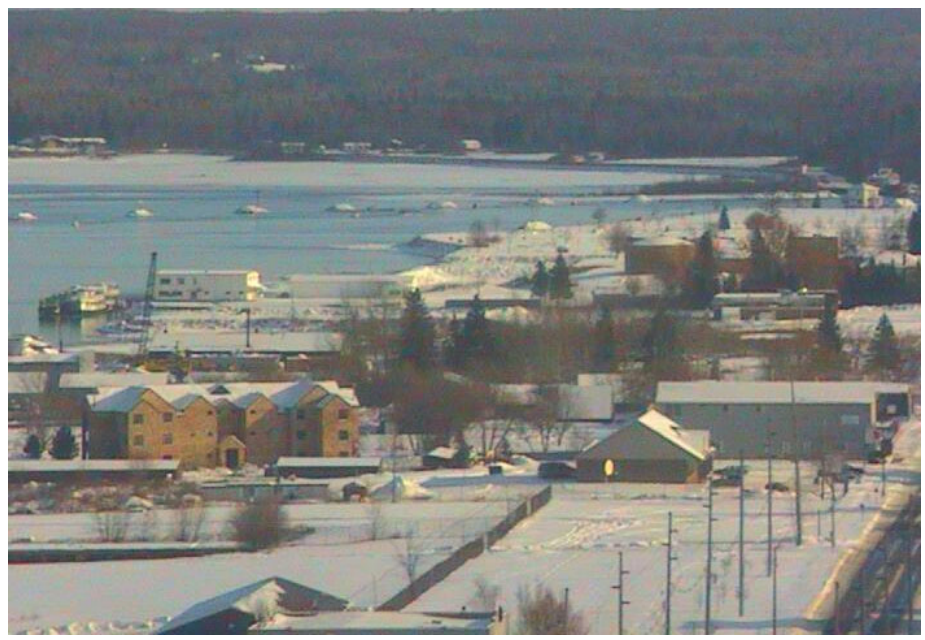

Figure 30. 14 December 2000. On this date, the ice cover extended well out from the north shore of Sugar Island.

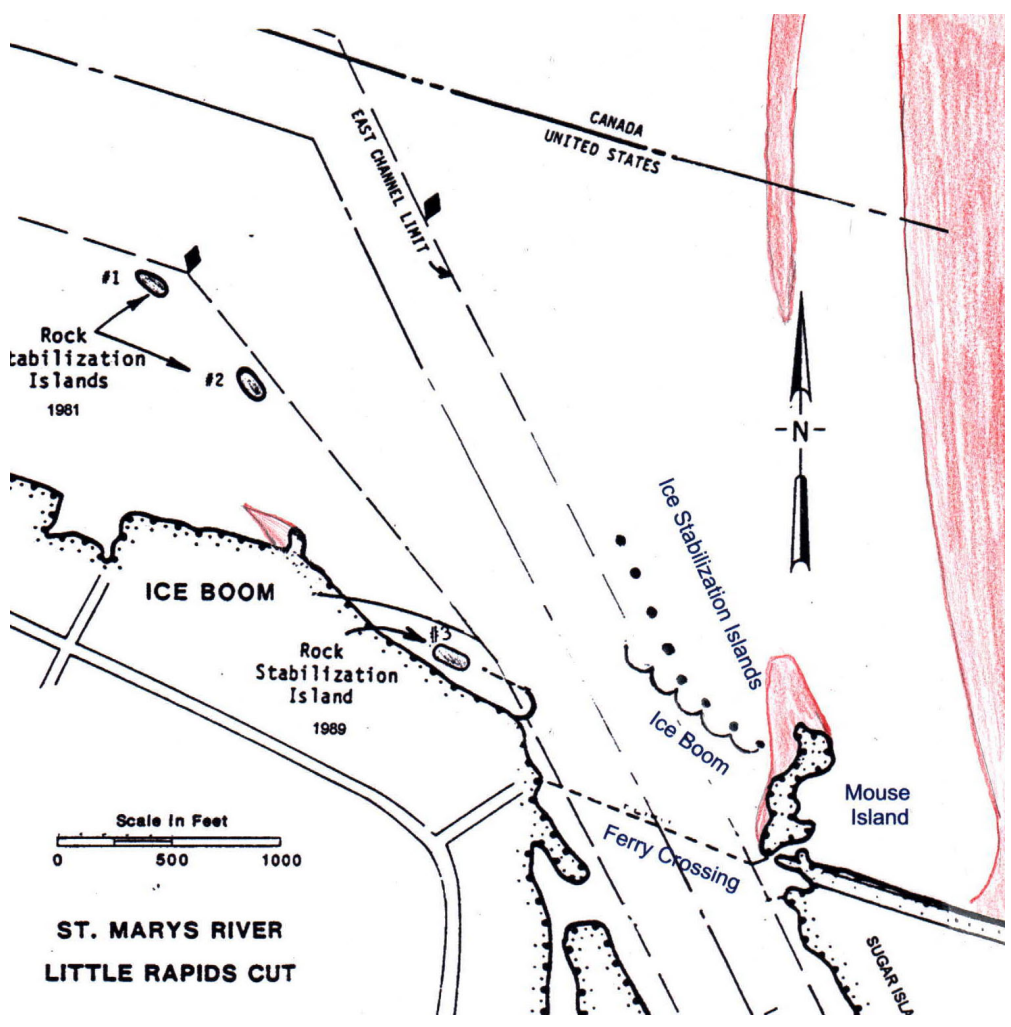

Figure 31. Ice conditions, 15 December 2000. Minor shore ice is building north of Mouse Island with a spit of ice forming upstream. 
By 24 December 2000 , the ice cover extended to within several hundred $\mathrm{ft}$ of the ice control islands (Fig. 32). The ice spit, visible on 14 December, had widened and connected with Mouse Island. Minor amounts of ice were collecting behind boom spans 1 and 2, indicating that the faster moving water in the channel had cooled nearly to the freezing point (Fig. 33).

By 28 December 2000, following four days of cold air temperatures, stable ice sheets covered both sides of the navigation channel, the east-side cover extending from the boom spans upstream past Islands 1-5 (Fig. 34 and 35). Two parallel leads to the east of the islands were visible, a small one passing between Islands 2 and 3 and a larger one extending upstream from the tip of Mouse Island.

Between 24 January and 18 March 2001, the ice cover was at its maximum extent, with the ice edges close to the 600-ft-wide navigation channel limits (Fig. 36 and 37). The boom spans and ice control islands delineated the eastern edge of the ice cover and a narrow lead was visible behind Islands 3, 4, and 5.

By 26 March 2001, the ice cover had begun to deteriorate. The ice edges had receded on both sides of the navigation channel and open water was visible behind Islands 3-8. Boom spans 2-5 retained broken floes (Fig. 38 and 39).

Through 31 March 2001, the open channel continued to widen until most of the ice on the west side had disappeared, and a lead was visible upstream of Mouse Island. Boom spans 2, 3, and 4 retained broken floes (Fig. 40 and 41).

The ice cover deterioration continued through 4 April 2001, at which time most of the area upstream of the Little Rapids Cut was ice-free (Fig. 42). 


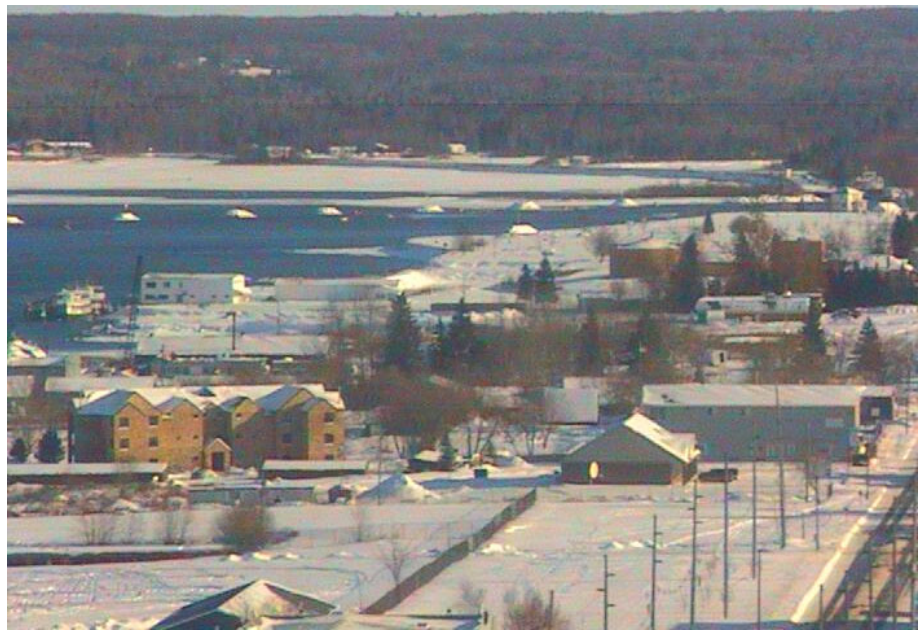

Figure 32. 24 December 2000. The ice cover extended to within several hundred feet of the ice control islands.

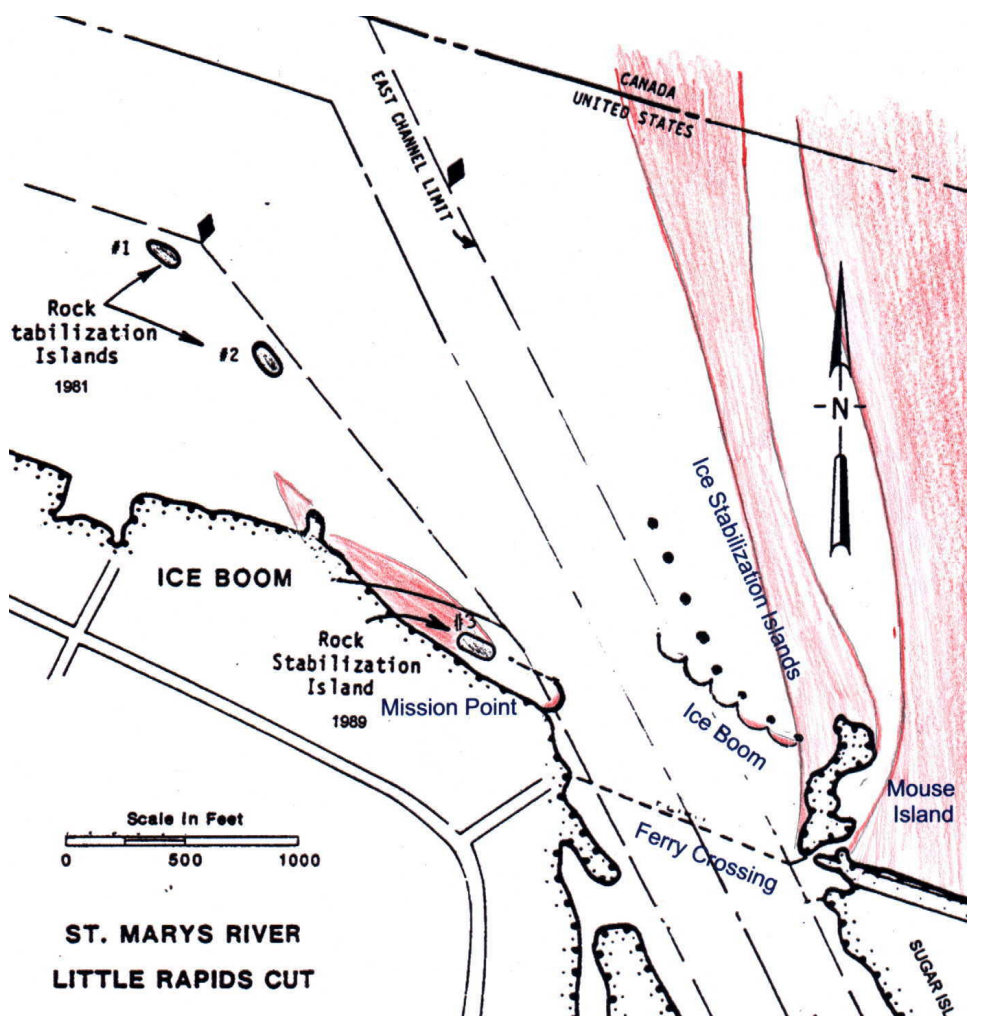

Figure 33. Ice conditions, 24 December 2000. The ice spit had connected with Mouse Island, and minor amounts of ice were collecting behind boom spans 1 and 2. 


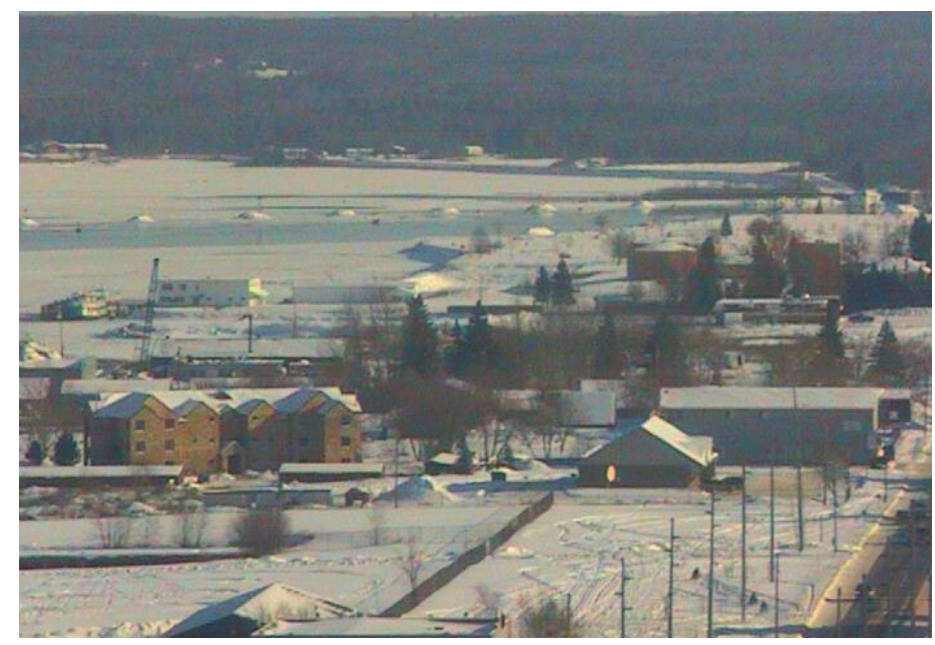

Figure 34. 28 December 2000. Stable ice extended from the boom spans upstream beyond Islands $1-5$.

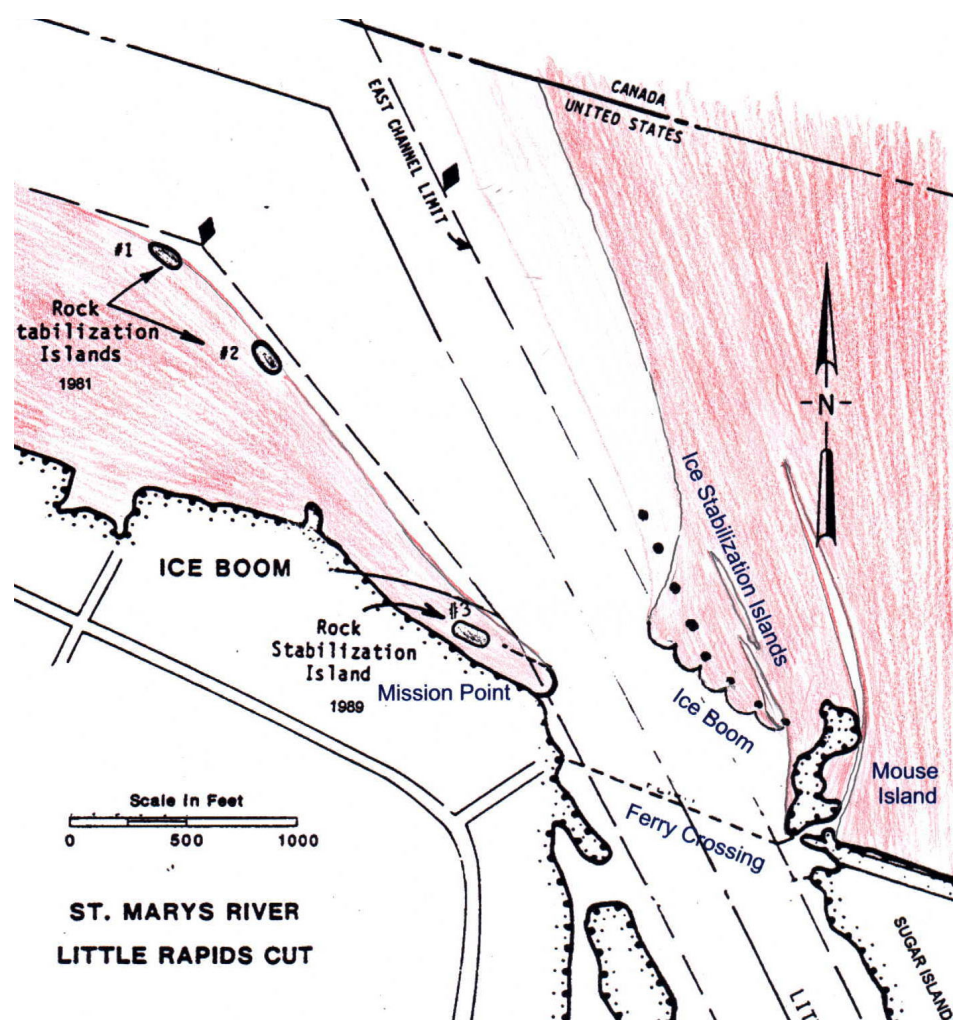

Figure 35. Ice conditions, 28 December 2001. Stable ice formed on both sides of the channel with two parallel leads to the east of the islands. 


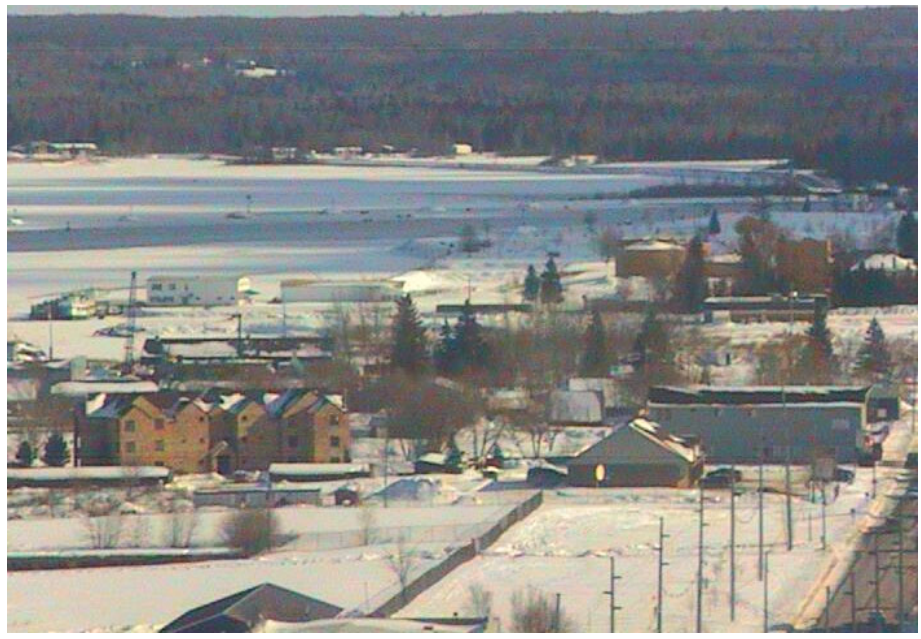

Figure 36. 24 January-18 March 2001. The ice cover was at its maximum during this time.

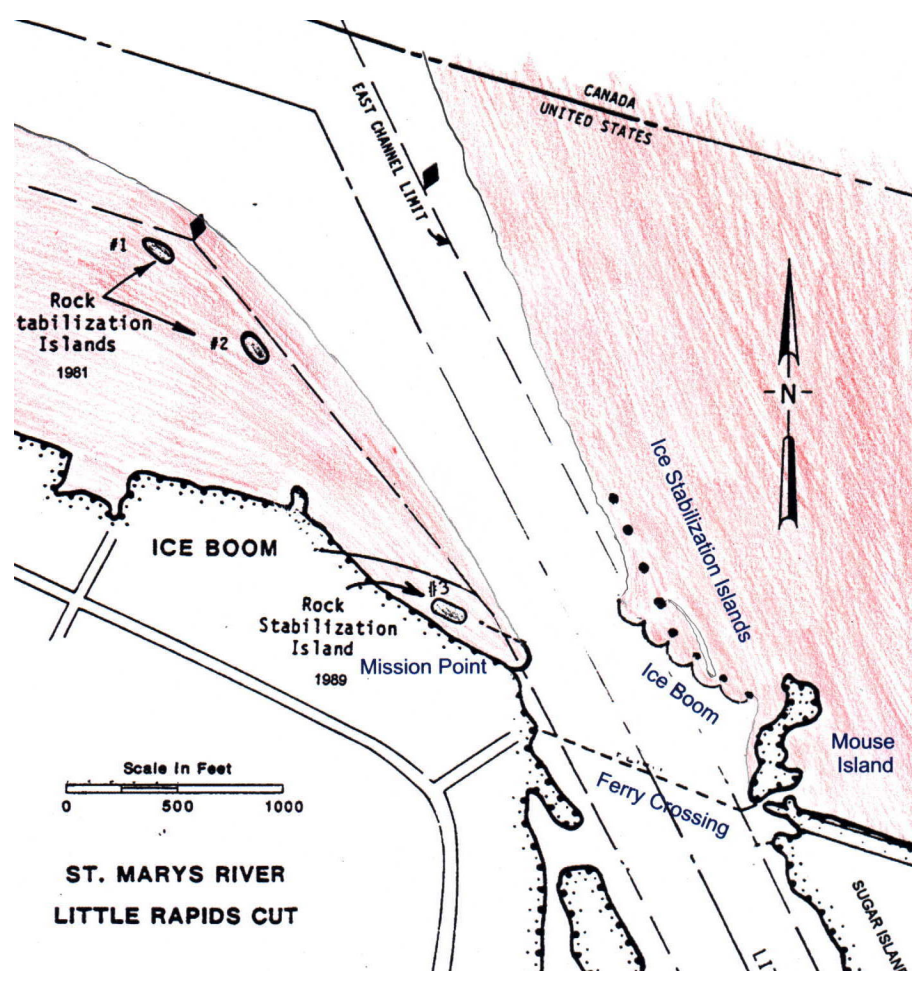

Figure 37. Ice conditions, 24 January-18 March 2001. There was stable ice on both sides of the navigation channel. Boom spans and islands delineate the eastern edge of the ice cover. 


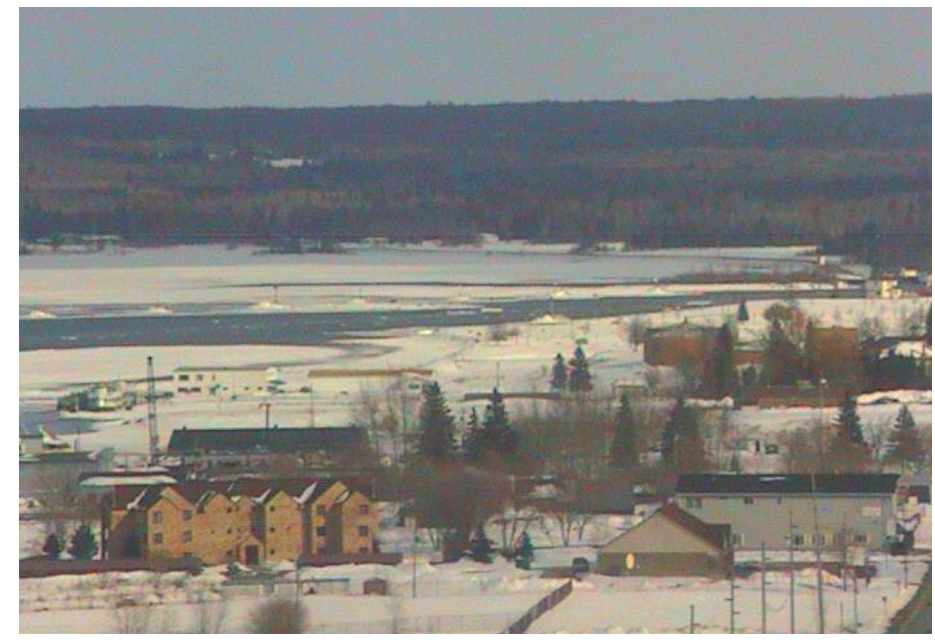

Figure 38. 26 March 2001. The ice cover had begun to deteriorate.

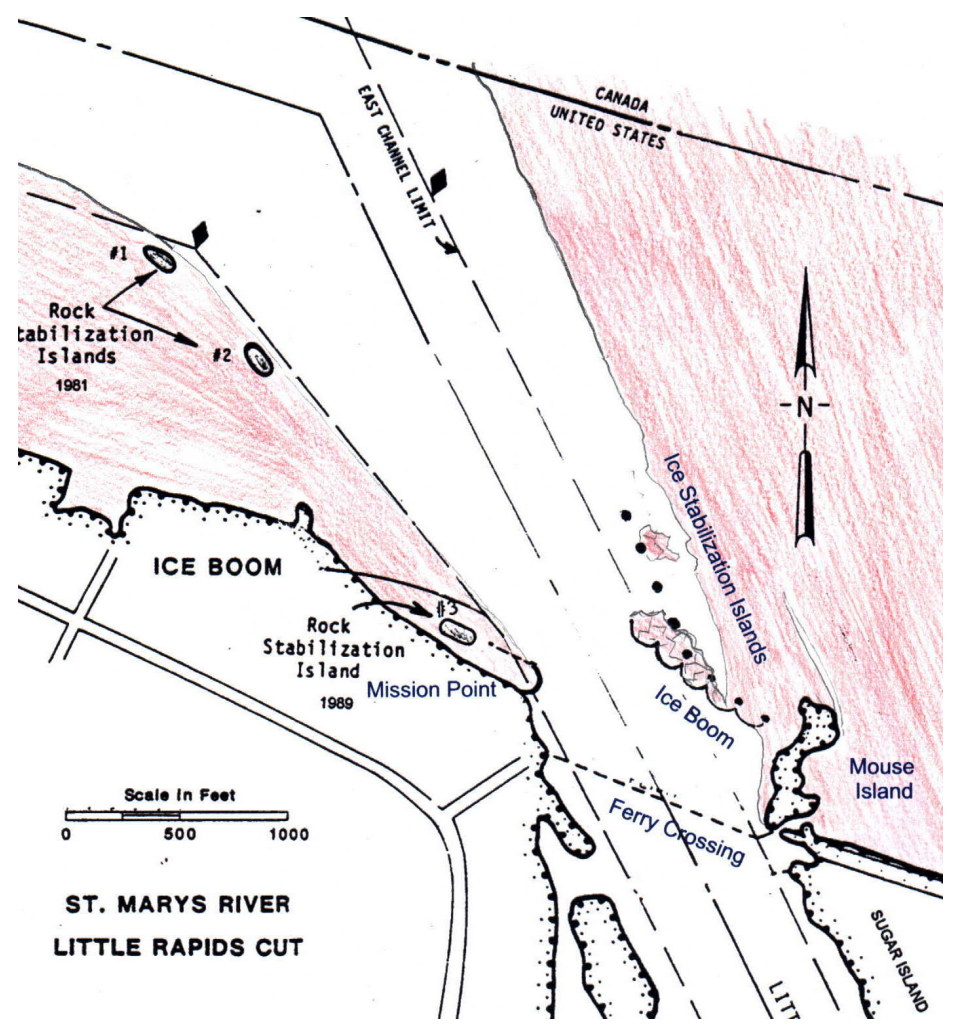

Figure 39. Ice conditions, 26 March 2001. The ice edge had receded on both sides of the navigation channel, open water was visible behind Islands 3-8, and boom spans 2-5 retained broken ice pieces. 


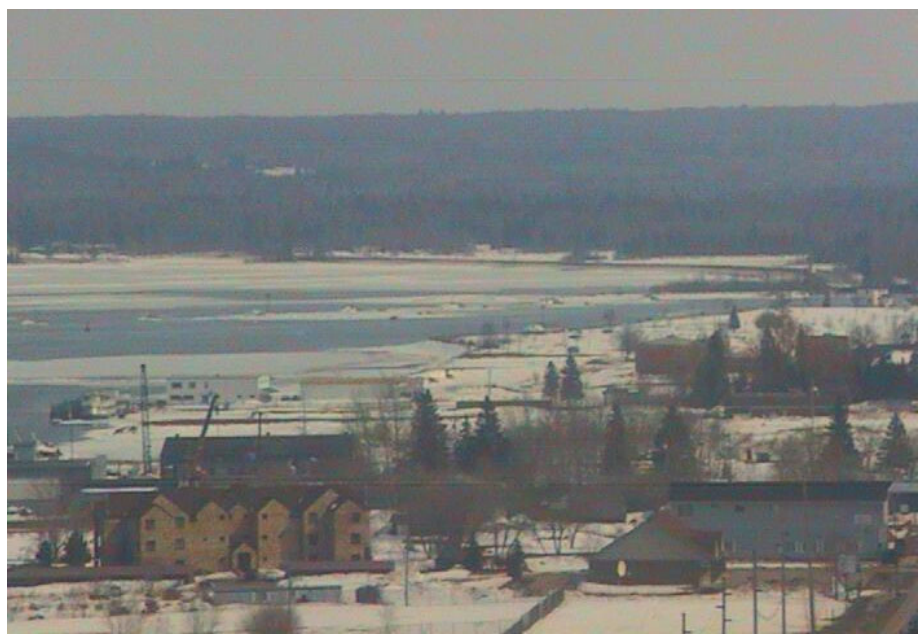

Figure 40. 31 March 2000. The channel continued to widen.

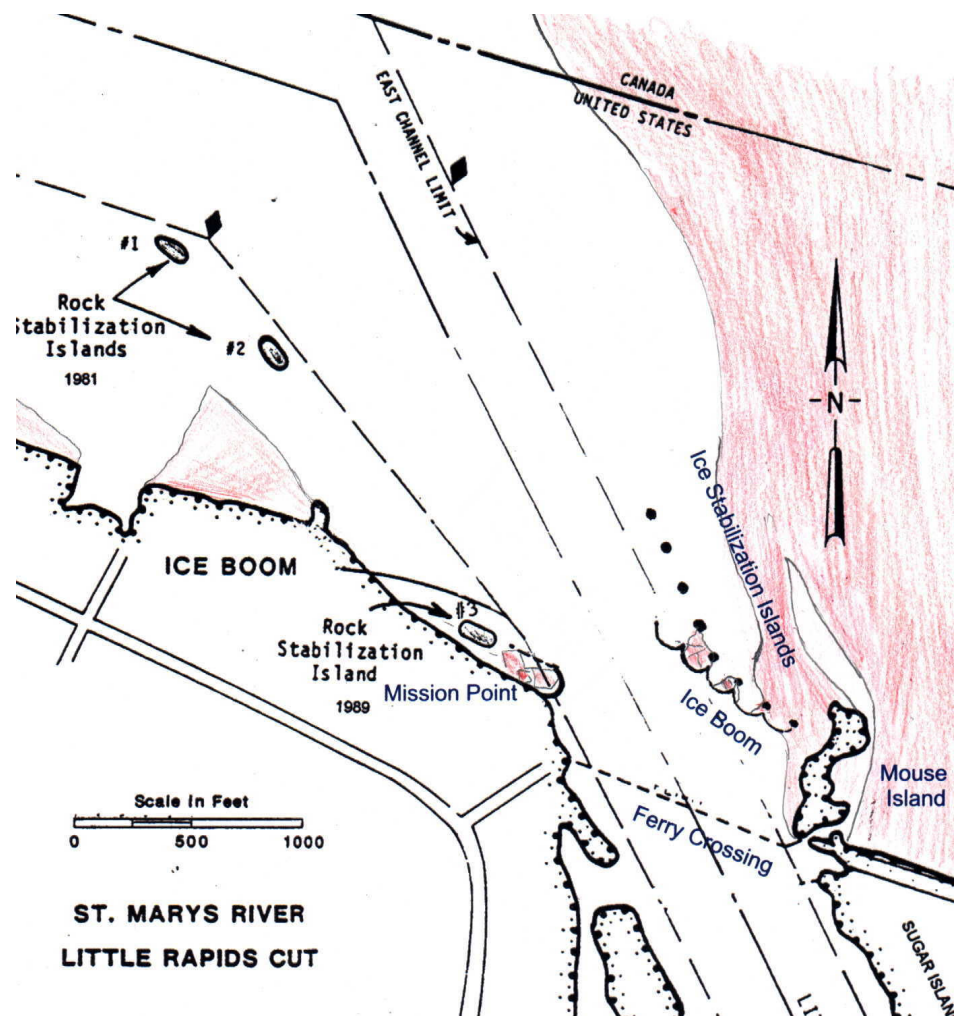

Figure 41. Ice conditions, 31 March 2001. Most of the ice on the west side of the channel had disappeared and a lead had appeared upstream of Mouse Island. Some of the boom spans retained broken floes. 


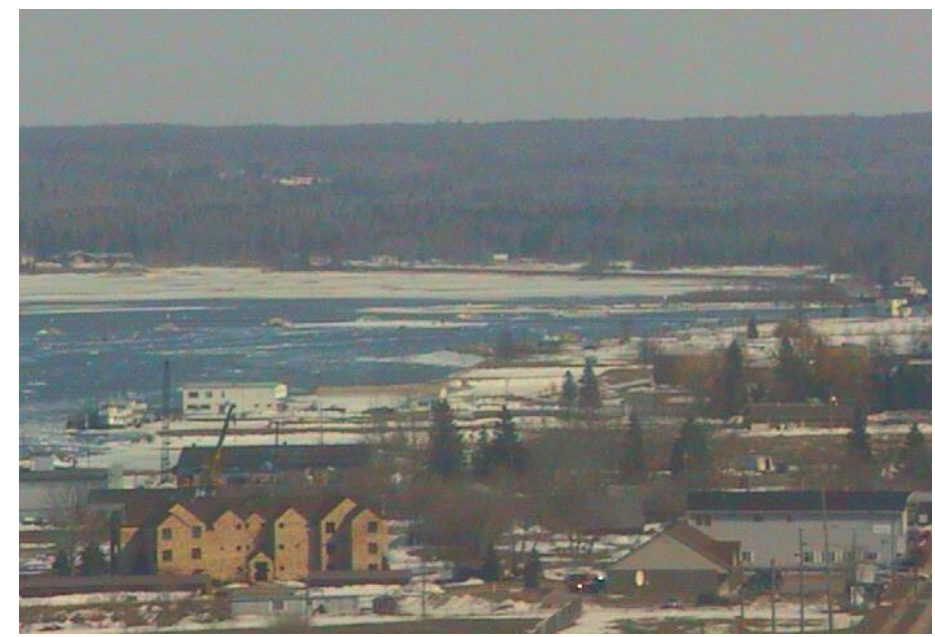

Figure 42. 4 April 2001. By this date, most of the area upstream of the Little Rapids Cut was ice-free. 


\section{SUMMARY AND CONCLUSIONS}

The video images from the winters of 1999-2000 and 2000-2001 suggest that the ice cover on the eastern side of the entrance to the Little Rapids Cut forms by two distinct processes. The first process is the growth of a sheet ice cover out from the northwest shore of Sugar Island, eventually reaching the edge of the navigation channel. The second process is an ice cover that initiates as frazil and small floes collect ice behind the boom spans and the ice stabilization islands. Based on the winter of 1999-2000 video images, the five boom spans appear to speed up the second ice formation process.

During January 2000, frazil slush and small floes accumulated initially behind boom spans 1,2 , and 3 , and the three islands immediately upstream of these spans. These unconsolidated ice accumulations in the vicinity of the booms and Islands 1-3 froze into a stable ice cover by mid January. The sheet ice cover to the east then progressed up to the edge of the navigation channel, surrounding Islands 5-8. The navigation channel arched across in late January, not at the narrowest point adjacent to the boom, but about $4000 \mathrm{ft}$ upstream. A week later, some large floes broke free from the arch and jammed in the constriction opposite the east arm of the boom. The ice control islands helped stabilize the ice on the eastern margin of the navigation channel through the midwinter period and also as the ice cover started to deteriorate in mid to late February 2000. During breakup, large floes piled up behind the islands, offering some degree of protection to the boom spans.

During the 2000-2001 ice season, the role of the boom spans and islands during the ice formation period was less obvious. This year the ice cover grew out from the northwest shore of Sugar Island, reaching easternmost Island 1 by 24 December 2000. By 28 December the cover was stable behind all the boom spans and Islands $1-5$. The ice never arched across the upstream navigation channel, so much of the ice generated between St. Marys Falls and Mission Point likely passed into the Little Rapids Cut.

Based on these two seasons of observation and the historic record of ice observations, it is clear that the ice processes vary significantly from year to year. Without the boom spans, the ice cover to the east of the navigation channel would likely reach and stabilize around the ice islands but the process would probably take longer. As a result, more ice would pass into the cut and potentially interfere with ferry operations. For mild winters such as 1998 and 1999, not installing the boom spans would probably have had little negative effect, but it is difficult to anticipate in November what a particular winter will bring. 
In conclusion, the boom spans have a positive role in initiating ice cover formation on the eastern edge of the navigation channel. The islands help stabilize the ice cover throughout the midwinter period and during the early part of breakup. 


\section{RECOMMENDATIONS}

Based on the two years of Web camera observations (1999-2000 and 20002001), we recommend the Soo Area Office continue to install the five boom spans on the east side of the entrance to the Little Rapids Cut each winter.

A maintenance-reducing measure might be to replace the timber boom with steel pipe pontoons as the timbers wear out. At a number of sites, including Lake Erie, the steel pipe pontoons are proving superior to wood both in terms of initial cost, lifespan, and ice retention capability. 


\section{LITERATURE CITED}

Acres American Inc. (1975) Model study of the Little Rapids Cut area of the St. Marys River, Michigan. Final Report. Acres American Inc., Buffalo, New York.

Cowley, J.E., J.W. Hayden, and W.W. Willis (1977) A model study of the St. Marys River ice navigation. Canadian Journal of Civil Engineering, Vol. 4: 380391.

Perham, R.E. (1978) Ice and ship effects on the St. Marys River ice booms. Canadian Journal of Civil Engineering, Vol. 5: 222-230.

Tuthill, A.M., and K.L. Carey (1996) St. Marys River ice boom replacement project: Ice island design options. Contract report for the U.S. Army Engineer District, Detroit. U.S. Army Cold Regions Research and Engineering Laboratory, Hanover, New Hampshire.

U.S. Army (1999) Ice Engineering. Engineer Manual 1110-1612. U.S. Army Corps of Engineers, Department of the Army, Washington, D.C. 


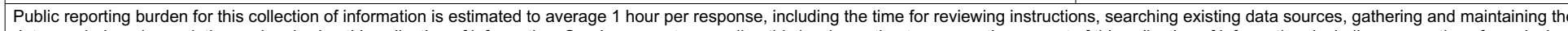

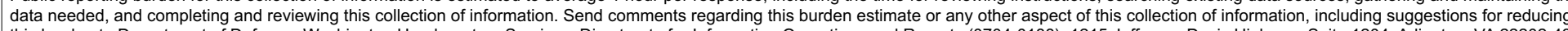

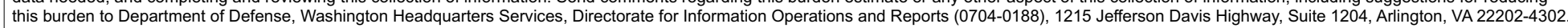

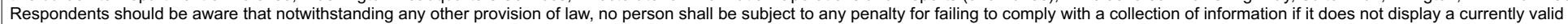
OMB control number. PLEASE DO NOT RETURN YOUR FORM TO THE ABOVE ADDRESS.
1. REPORT DATE (DD-MM-YY)
May 2002
2. REPORT TYPE
Technical Report

4. TITLE AND SUBTITLE

Videomonitoring Performance of the

St. Marys River Ice Islands and Ice Boom

\section{AUTHOR(S)}

Andrew M. Tuthill and John J. Gagnon

\section{PERFORMING ORGANIZATION NAME(S) AND ADDRESS(ES)}

U.S. Army Engineer Research and Development Center

Cold Regions Research and Engineering Laboratory

72 Lyme Road

Hanover, NH 03755-1290

\section{SPONSORING/MONITORING AGENCY NAME(S) AND ADDRESS(ES)}

Office of the Chief of Engineers

Washington, DC

\section{DISTRIBUTION / AVAILABILITY STATEMENT}

Approved for public release; distribution is unlimited.

Available from NTIS, Springfield, Virginia 22161.
3. DATES COVERED (From - To)

5a. CONTRACT NUMBER

5b. GRANT NUMBER

5c. PROGRAM ELEMENT NUMBER

5d. PROJECT NUMBER

5e. TASK NUMBER

5f. WORK UNIT NUMBER

8. PERFORMING ORGANIZATION REPORT NUMBER

ERDC/CRREL TR-02-8

10. SPONSOR / MONITOR'S ACRONYM(S)

11. SPONSOR / MONITOR'S REPORT NUMBER(S)

13. SUPPLEMENTARY NOTES

\section{ABSTRACT}

In 1997, six islands were constructed to stabilize the ice cover at the entrance to the Little Rapids Cut on the St. Marys River at Sault Ste. Marie, Michigan. It was hoped that the artificial islands would eliminate the need for an ice retention boom installed annually since 1974 by the Corps of Engineers. The U.S. Army Cold Regions Research and Engineering Laboratory (CRREL) videomonitored the performance of the ice control islands during the winters of 2000 and 2001. Conclusions were that, although the islands helped stabilize the ice cover and protected the ice boom from impacts from large ice floes, the boom should still be installed as it significantly speeds ice cover formation at the Little Rapids Cut entrance.

15. SUBJECT TERMS

Animation

Ice boom
Ice control
Videomonitoring

Web camera
Ice stabilization islands

Winter navigation

\begin{tabular}{|c|c|c|c|c|c|}
\hline \multicolumn{3}{|c|}{ 16. SECURITY CLASSIFICATION OF: } & \multirow{2}{*}{$\begin{array}{l}\text { 17. LIMITATION OF } \\
\text { OF ABSTRACT }\end{array}$} & \multirow{2}{*}{$\begin{array}{l}\text { 18. NUMBER } \\
\text { OF PAGES }\end{array}$} & 19a. NAME OF RESPONSIBLE PERSON \\
\hline a. REPORT & b. ABSTRACT & c. THIS PAGE & & & 19b. TELEPHONE NUMBER (include area code) \\
\hline $\mathrm{U}$ & $\mathrm{U}$ & $\mathrm{U}$ & $\mathrm{U}$ & 45 & \\
\hline
\end{tabular}

Standard Form 298 (Rev. 8-98)

Prescribed by ANSI Std. 239.18 


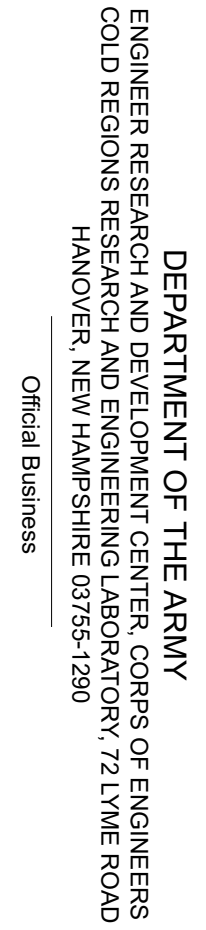

